12-16-2015

\title{
Geomorphic and geologic controls of geohazards induced by Nepal's 2015 Gorkha earthquake
}

\author{
J. S. Kargel
}

G. J. Leonard

Dan H. Shugar

University of Washington Tacoma, dshugar@uw.edu

U. K. Haritashya

A. Bevington

See next page for additional authors

Follow this and additional works at: https://digitalcommons.tacoma.uw.edu/ias_pub

\section{Recommended Citation}

Kargel, J. S.; Leonard, G. J.; Shugar, Dan H.; Haritashya, U. K.; Bevington, A.; Fielding, E. J.; Fujita, K.; Geertsema, M.; and Miles, E. S., "Geomorphic and geologic controls of geohazards induced by Nepal's 2015 Gorkha earthquake" (2015). SIAS Faculty Publications. 342.

https://digitalcommons.tacoma.uw.edu/ias_pub/342 
Authors

J. S. Kargel, G. J. Leonard, Dan H. Shugar, U. K. Haritashya, A. Bevington, E. J. Fielding, K. Fujita, M. Geertsema, and E. S. Miles 
1 Geomorphic, Tectonic, and Geologic Controls of Geohazards Induced by Nepal's 2015 Gorkha Earthquake

3

*J.S. Kargel, ${ }^{1 *}$ G.J. Leonard, ${ }^{1}$ D.H. Shugar, ${ }^{2}$ U.K. Haritashya,${ }^{3}$ A. Bevington, ${ }^{4}$ E.J. Fielding, ${ }^{5}$ K. Fujita, ${ }^{6}$ M. Geertsema, ${ }^{4}$ E.S. Miles, ${ }^{7}$ J. Steiner ${ }^{8}$; and E. Anderson, ${ }^{9}$ S. Bajracharya, ${ }^{10}$ G.W. Bawden, ${ }^{11}$ D.F. Breashears, ${ }^{12}$ A. Byers, ${ }^{13}$ B. Collins,${ }^{14}$ E. CzyzowskaWisniewski, ${ }^{15}$ M.R. Dhital, ${ }^{16}$ A. Donnellan, ${ }^{5}$ T.L. Evans, ${ }^{17}$ M.L. Geai, ${ }^{18}$ M.T. Glasscoe, ${ }^{5}$ D. Green, ${ }^{11}$ D.R. Gurung, ${ }^{10}$ R. Heijenk, ${ }^{4}$ A. Hilborn, ${ }^{17}$ K. Hudnut, ${ }^{19}$ C. Huyck, ${ }^{20}$ W.W. Immerzeel, ${ }^{21}$ JIANG Liming, ${ }^{22}$ R. Jibson, ${ }^{23}$ A. Kääb, ${ }^{24}$ N.R. Khanal, ${ }^{10}$ D. Kirschbaum, ${ }^{25}$ P.D.A. Kraaijenbrink, ${ }^{21}$ D. Lamsal ${ }^{26}$ LIU Shiyin, ${ }^{27}$ LV Mingyang, ${ }^{28}$ D. McKinney, ${ }^{29}$ N. K. Nahirnick, ${ }^{17}$ NAN Zhuotong, ${ }^{27}$ S. Ojha, ${ }^{26}$ J. Olsenholler, ${ }^{30}$ T.H. Painter, ${ }^{5}$ M. Pleasants, ${ }^{3}$ Pratima KC, ${ }^{15}$ QI Yuan, ${ }^{27}$ B.H. Raup,${ }^{31}$ D. Regmi, ${ }^{32}$ D.R. Rounce, ${ }^{33}$ A. Sakai, ${ }^{6}$ SHANGGUAN Donghui, ${ }^{27}$ J.M. Shea, ${ }^{10}$ A.B. Shrestha, ${ }^{10}$ A. Shukla,${ }^{34}$ D. Stumm, ${ }^{10}$ M. van der Kooij, ${ }^{35}$ K. Voss, ${ }^{36}$ WANG Xin, ${ }^{37}$ B. Weihs, ${ }^{38}$ D. Wolfe, ${ }^{39}$ WU Lizong, ${ }^{28}$ YAO Xiaojun, ${ }^{40}$ M.R. Yoder, ${ }^{41}$ and N. Young ${ }^{42}$

${ }^{1}$ Corresponding author: Department of Hydrology \& Water Resources, University of Arizona, Tucson, AZ, USA; Email: kargel@hwr.arizona.edu. See Supplement for full author affiliations.

\section{ABSTRACT}

The Gorkha earthquake (M 7.8) on 25 April 2015 and later aftershocks struck South Asia, killing $\sim 9,000$ and damaging a large region. Supported by a large campaign of responsive satellite data acquisitions over the earthquake disaster zone, our team undertook a satellite image survey of the earthquakes' induced geohazards in Nepal and China and an assessment of the geomorphic, tectonic, and geologic controls on quake-induced landslides. Timely analysis and communication aided response and recovery and informed decision makers. We mapped 4312 co-seismic and post-seismic landslides and surveyed 491 glacier lakes for earthquake damage, but found only 9 landslide-impacted lakes and no visible satellite evidence of outbursts. Landslide densities are correlated with slope, peak ground acceleration, surface downdrop, and specific metamorphic lithologies and large plutonic intrusions.

\section{Introduction}

On 25 April 2015 and over the next several weeks, a major series of displacements occurred $\sim 15 \mathrm{~km}$ deep along the buried Main Himalayan Thrust without breaking the surface (1-3). The main shock of the Gorkha earthquake (M 7.8, USGS; epicenter $28.147^{\circ} \mathrm{N}, 84.708^{\circ} \mathrm{E}$ ) was followed by $\sim 257$ aftershocks $>$ M 3.0 including 5 $\geq \mathrm{M} 6.0$ between 25 April and 10 June 2015. On 12 May, a M 7.3 aftershock struck $\sim 150$ $\mathrm{km}$ ENE of the main shock. The largest earthquakes caused a wide swath of death and destruction in Nepal and within adjacent India, China, and Bangladesh. Some mountain 
44 villages were shaken to complete destruction (c.f., 4), buried by avalanches and

45 landslides, or destroyed by powerful avalanche and landslide air blasts. The remote

46 locations and blocked roads and rivers meant that ground crews could not immediately access many Himalayan valleys, and aircraft were insufficient for rapid assessment.

A satellite-based approach was adopted to examine the vast damaged region. Satellite imagery was provided by NASA, DigitalGlobe, the Japan Aerospace Exploration Agency (JAXA), MacDonald Dettwiler and Associates (MDA), Planet Labs, Spot Image, and the China National Space Administration, including imagery triggered by the International Charter: Space and Major Disasters (http://www.disasterscharter.org). A "Volunteer Group" of analysts from nine nations was organized by the University of Arizona under the auspices of Global Land Ice Measurements from Space (GLIMS) (5) initially to assess priority hazard situations and then to build a landslide inventory ( $\sigma$ ). The group - most of the authors - contributed their input of mapped geohazards to a broad ad hoc NASA-led interagency "Response Team." To date, the group has scrutinized optical imagery, ranging from $15 \mathrm{~m}$ resolution to $<1 \mathrm{~m}$, from Landsats 7 and 8 , the Advanced Spaceborne and Thermal Emission and Reflection Radiometer (ASTER) onboard Terra, Advanced Land Imager on EO-1, WorldView-1, -2, and -3, GeoEye-1, Pleiades, and Gaofen-1 (Table S1), and utilized radar data from ALOS-2 and RADARSAT-2, and topography from the Shuttle Radar Topography Mission (SRTM). Landslides not detectable at these scales would generally have lower human consequences than larger landslides.

The Response Team, including the Volunteer Group, undertook one of the broadest and fastest international emergency remote sensing and data analysis campaigns ever led by NASA for any earthquake-affected region (7-9). Parallel, but independent landslide mapping efforts have been undertaken by a joint British Geological SurveyDurham University group (10) and other groups.

During previous earthquake emergencies in mountainous terrain (e.g., Wenchuan, China; Denali, Alaska), landslides were numerous (9, 11-17), sometimes initiating a process chain of secondary and tertiary geomorphic processes over time-spans ranging from minutes to years after the earthquake (18). Landslide-initiated process chains may involve gains in mobilized mass and destructive power through energy and mass transfer cascades. Many documented or inferred examples exist, including rock/ice fall-generated debris avalanches that transformed into debris flows $(19,20)$ or caused large impoundment lakes and upstream flooding (21); landslide-generated displacement waves and glacier lake outburst floods (GLOFs) $(22,23)$; and landslide-dammed lake outbursts $(24,25)$. As debris, ice, lake and stream water are ingested into an outburst flood, a debris flow or hyper-concentrated slurry flood may result (e.g. 20). Each geomorphic process in the chain may trigger a subsequent geohazard and extend the damaging reach of the event $(26,27)$. Process chains involving GLOFs are particularly worrisome.

The Volunteer Group's work focused on systematic mapping of quake-induced geohazards, understanding the geomorphic, lithologic and tectonic control of their distribution, and the identification of communities and infrastructure that might be affected. Using mainly satellite-based findings, supplemented with media reports and eyewitness photography, a rapid field assessment by the U.S. Geological Survey (USGS), and modeling of lake outburst flood processes, we analyze the distribution and character 89 of the geohazards induced by the Gorkha earthquake in Nepal and Tibet. 


\section{Landslide mapping and assessment}

We mapped the distribution of 4,312 earthquake-induced (co-seismic and post-

\section{Landslide distribution: control by shaking and slope}

The locations of the Gorkha earthquake-induced landslides are plotted in Figure 1 with landscape physiography and the epicenters of the six largest shocks (1A), PGA (1B), reported deaths (1C), and slope (Fig. 1D). Fig. 1E represents the smoothed landslide density distribution. We also computed and mapped the susceptibilities of the landscape to earthquake-induced mass movements of ice, snow, or rock (Fig. 2). The computed susceptibilities depend on the product of the sine of slope (32) and the PGA (from the USGS ShakeMap PGA, Fig 1B). The distribution of lakes that were examined in satellite images for earthquake-related damage is shown on a base map of PGA in Fig. 2D (discussed below). 

index partly accounts for where landslides occurred (Fig. 2), especially where collapse of high-elevation snow and ice may have been involved (Figs. 2B, 2C). The landslide distribution shows the strongest associations with slopes $>30^{\circ}$ (Fig. 1C, 3A), PGA $>0.32$ g (Fig. 2A, 3B), and shake-induced landslide susceptibility index $>0.16$ g (Fig. 2A). We infer that many of these landslides probably would not have occurred anytime soon without earthquake shaking. The control of landslide occurrences by the steep Himalayan slopes and seismic shaking is unsurprising and similar to other well-documented earthquakes (33). However, landslide susceptibilities differ from quake to quake. These new results detail the relationships of this Himalayan earthquake to seismic and geologic/terrain parameters.

\footnotetext{
Fig. 1. Location of 4312 earthquake-related geohazard. (A) Distribution of glaciers (blue), late-season snowfields (red), landslides (white dots), and main shock and largest aftershock epicenters. The base topography is from the SRTM 90 m gap-filled DEM (32). Glacier extents are from the Randolph Glacier Inventory (RGI) (34). Snowfields were derived from pre-event Landsat-8 VNIR-SWIR band ratios and topographic masks. (B) Landslides plotted with local peak ground accelerations induced by the main Gorkha shock or $>6 \mathrm{M}$ aftershocks. PGAs from U.S. Geological Survey's USGS-NEIC ShakeMap (35). Inset panels b1 and b2 are enlarged to show details near Langtang and Pisang. (C) Landslides plotted with reported deaths per Nepal district are from the Government of Nepal, Nepal Disaster Risk Reduction Project. (D) Hazard occurrences (black dots) on calculated slopes. Inset shows detail of hazard-dense region. (E) Smoothed area density (log scale) of earthquake-induced landslides determined using a neighborhood $1 / 8^{\circ} \times 1 / 8^{\circ}$ search window $(\sim 14 \mathrm{~km} \times 12 \mathrm{~km})$ in relation to major $(\geq \mathrm{M} 6)$ epicenters of historic earthquakes and the Gorkha quakes (35). Densities range between $0.01-3.37$ landslides $/ \mathrm{km}^{2}$. Higher landslide densities occur locally on scales finer than $1 / 8^{\circ}$.
}

Fig. 2. Debris landslide susceptibility with mapped hazards. (A) Susceptibility in units of acceleration divided by $g\left(9.81 \mathrm{~m} \mathrm{~s}^{-2}\right)$. (B) Snow avalanche susceptibility with mapped hazards. Susceptibility in $g$. (C) Ice avalanche susceptibility with mapped hazards. Susceptibility in $g$. (D) Maximum PGA experienced by 491 glacier lakes. Mapped hazards shown as white dots. Maximum PGA for glacier lakes was $0.57 \mathrm{~g}$. Insets show detail is Langtang Valley.

As PGA attains several tenths of $g$, shake-induced coseismic failures are not restricted to materials and terrains that were already poised near failure; whole mountainsides can collapse. Whereas landsliding on steep, strongly shaken slopes is easily understood, the tail of the landslide distribution to low shaking values, to low slopes, and low (but non-zero) shaking-induced landslide susceptibilities (Fig. 3) requires further explanation. The mechanisms outlined below may produce landslides or avalanches at low but non-zero shaking in granular materials occurring on steep slopes, in water-saturated sediments, and on steeply sloping, basally melted glaciers. The deadly Mount Everest ice/snow avalanches on 25 April 2015 exemplify this point, where shaking was a low $0.09 \mathrm{~g}$ (Table S3). Slopes there are steep, and glacier ice and snow are commonly poised near failure as indicated by Everest's history of ice avalanches, including back-to-back years of record 16 avalanche deaths in April 2014 (triggered by spring melting) and 22 in April 2015 (earthquake-triggered). Many Himalayan glaciers are substantially avalanche-fed, and snow or ice avalanches may occur upon a slight prompt, whether due to heavy winter or monsoon snowfall, or spring melting, or slight shaking. The Gorkha earthquake struck soon after another year of spring melting began, and Everest's ice and snow probably again was near collapse. Landslides in the upper 
Marsyangdi Valley (described below) also experienced relatively weak shaking (0.11- 
limb of the hanging wall of the thrust structure and counter-intuitively correlates with the higher Himalaya. Within this block, landslide densities increase southward and then abruptly decrease near the tectonic hingeline, which separates the downdropped and upthrown blocks (and also approximates the zone of maximum slip on the fault). RADARSAT-2 data provide the horizontal displacement field over part of the earthquake-affected region and confirm that the largest horizontal displacements (Fig. 4B) are near the hingeline and in the uplifted block as defined by vertical deformation (Fig. 4A).

The distinctive concentration of earthquake-induced landslides in the tectonic downdropped block of the Gorkha earthquake is not fully understood. The steep slopes within the downdropped block no doubt contributed to the pattern of landslide densities, but steep slopes are also present in some areas where landslides are few. A possibility is that the net downward acceleration implied by the downdrop caused a momentary reduction in lithostatic stress, hence a reduction of normal stress along inclined planes of weakness. Relief of normal stress could have allowed nonlithostatic shear stress, including lateral seismic acceleration, to initiate motion along landslide failure planes. Because the coefficient of sliding friction is normally less than that of static friction, motion may then continue and drive a landslide. The same mechanism may apply to shaking, and hence, the broad-field deformation may impose a modulation on the shaking-induced perturbation of normal stress, again suggesting some integration of multiple causative trigger mechanisms.

The Gorkha earthquake caused fewer than expected landslides for an earthquake of that magnitude (e.g., 12,31), mirroring the relative paucity of destruction of dwellings compared to what may have been expected (2). The peculiar distribution of the Gorkha earthquake landslides on the downdropped block (Fig. 4) placed them mainly north of the major population centers, no doubt reducing the death toll. For strike-slip events such as the 2010 M7.0 Haiti earthquake (44), landslides were not similarly distributed systematically with respect to the fault plane. In the 1994 M6.7 Northridge and 2008 M7.9 Wenchuan earthquakes $(11,12,45)$, which like the Gorkha quake were both oblique thrust events, landslides were concentrated on the up-thrown block, which were also the higher, mountainous areas. The M7.9 Wenchuan 2008 earthquake induced far more landslides than the Gorkha earthquake, despite similar steep terrain. These differences might relate to the Gorkha quake's shallow dipping fault and lack of surface rupture (a blind thrust).

The Northridge earthquake was also a blind thrust, and despite being smaller than the Gorkha quake, it produced 11,000 documented landslides (45). Some, mapped by an airborne survey, were smaller than the detection limit in the imagery used for our survey where Digital Globe data were unavailable. The numerous slides caused by the Northridge earthquake may be primarily attributed to uncemented clastic sedimentary compositions dominating the regional lithology, versus more competent high-grade metamorphic and igneous rocks dominating the higher Himalaya. The differing types and densities of vegetation and root binding might also be a factor. In general, differences in earthquake-induced landslide densities can also be related to the number and magnitude of strong high-frequency ground motions, though the paucity of strong-motion recordings in the cases of both the Gorkha and Wenchuan quakes hampers comparison. 
Fig. 4. Landslide distribution relative to the Earth surface deformation field. (A) 4312 landslides (yellow dots) are concentrated mostly north of the hinge-line between the downdropped block and uplifted block. Also shown are the epicenters of the main shock and five largest aftershocks. Displacements are from the JAXA ALOS-2 ScanSAR interferogram (21 Feb 21 and 2 May 2015 scenes), which represent almost entirely vertical motion. ALOS-2 interferometry of the Gorkha earthquake and largest aftershock was recently described by Lindsey et al. (3). (B) Horizontal motion map based on azimuth shift measurements of the Radarsat-2 XF acquisitions of 5 April 5 and 29 April 2015. Scale shows motion excluding outliers outside the mean $\pm 3 \sigma$. Values are positive for SSW azimuths $>100$ degrees v. east. Hence, both the upthrown and downdropped blocks shifted southward.

\section{Landslide distribution: control by lithology and major fault structure}

The local clustering indicates that there are additional controls on landslide occurrence. Lithologic variations, sediment thickness, bedding dip direction relative to slope aspect, extent of physical and chemical weathering, and vegetation cover may be important controlling factors. No doubt, lithology has affected the occurrence of some landslides; e.g., failure of, or ingestion of ice and unconsolidated glacial debris was involved in the Langtang Valley slides, and poorly consolidated sediment dominated in the Marsyangdi Valley landslides (both are discussed below). We now consider bedrock lithology and the indirect control by fault structure (Fig. 5).

Fault structures exert indirect control of the clustering of landslides and organization of clusters. Figure 5 shows high concentrations of landslides within particular Proterozoic metamorphic units and intrusive complexes (described below) and close to the surface traces of several major tectonic features, mainly low-angle thrust faults including the South Tibetan Detachment System (STDS), Main Central Thrust (MCT), Main Boundary Thrust (MBT), and the Main Frontal Thrust (MFT); the latter three faults splay off the subsurface Main Himalayan Thrust, which is thought to have slipped during these earthquakes (1). However, because none of the Gorkha earthquake fault displacements (main shock or aftershocks) are known to have pierced the surface, the association with the thrust faults might indicate underlying lithological control, where the faults, over geologic time, have juxtaposed rocks of differing compositions at the surface. Lithologic properties influence the topographic character of the landscape and how seismic energy is transmitted, particularly through their (i) elastic and brittle/elastic properties, (ii) chemical weathering and control on erosion and slope, (iii) fracture development and fault displacement, and (iv) seismic wave interactions with topography and lithological structures. Each factor likely contributes, where lithology is a common denominator.

Fig. 5. Landslide occurrence on mapped geologic units. Geology from simplified geologic map by (46, 47)) and major faults (48).

A high density of landslides occurs within the upper Lesser Himalaya near and east from the epicenter of the primary earthquake. Whereas this cluster's proximity to the largest shock's epicenter is evident, the pattern defined by the cluster is closely correlated with the outcrop of the upper Lesser Himalaya, which is composed of low- to medium-grade metamorphosed Proterozoic argillic-calcareous (clay + sand) units and with adjacent higher grade metamorphic Proterozoic rocks. The upper Lesser Himalaya 
here is bounded on the north by the Main Central Thrust, where the overthrusted rocks are dominated by Precambrian gneisses, but only near the thrusted contact does the latter contain many landslides. Lithological control on landslide is evident, perhaps especially where there is strong lithological contrast.

Many landslides occur south and west of Kathmandu (Fig 5) near the Main Central Thrust (MCT) of the Kathmandu Nappe (a thrust sheet of Precambrian/Lower Paleozoic meta-sedimentary rocks as mapped by Stöcklin (46). In these areas, landslides are especially concentrated where Ordovician granitoids have intruded metasediments, suggesting lithological contrast as a controlling feature. Remarkably, the north side of the Kathmandu Nappe, though containing a similar sequence of rocks (but lacking large granitoid intrusions), was not as strongly affected by earthquake-related landsliding; yet it was closer to the primary shock.

Proterozoic slate, shale, siltstone, sandstone, and graphitic schist-all layered rock types - host a low density of landslides (Fig. 5). Landslides have the most heterogeneous distribution in the rock sequence indicated in Fig. 5 as Proterozoic phyllite, amphibolite, metasandstone, and schist (and mapped by Stöcklin (46) as Precambrian gneisses). The landslide density in this undifferentiated metamorphic rock sequence ranges from very low to very high. The landslide hotspots comprise a small fraction of the area of this widespread rock unit. Steep-sided, high-elevation ridgetops generated some of the landslide hotspots in this geologic unit; for example Langtang Valley landslides largely originated high on the ridges and near the summits in places where glaciers, glacial debris, and bedrock failed. The lithological controls may be manifested through rock mechanics and rock weathering and slope.

Wave interactions and influences on landsliding may also have been affected by different rock types' contrasting speeds of s-, p-, and surface waves, resultant scattering and wave interference, and heterogeneous energy dissipation as seismic waves traversed the rugged Himalayan topography. Supporting the idea of local wave interactions, during helicopter overflights authors B. Collins and R. Jibson (49) observed pervasive ridgetop shattering through much of the landsliding region. In the Northridge earthquake (50) ridgetop shattering was attributed to constructive wave interference and the focusing of seismic energy into ridges. This phenomenon has also been modeled for the case of an earthquake in a rugged area of Taiwan (51). Finally, damage related to wave resonance occurred in the Kathmandu Basin during the Gorkha earthquake (2), and similar resonant effects may have occurred elsewhere at damaging frequencies affected by the spatial scales and geometry of various lithologic units. Human-built structures of different sizes and construction, having unique resonant vibrational frequencies, were selectively destroyed.

Some major river valleys also have high landslide densities, including along the Marsyangdi and Trishuli rivers. In the Marsyangdi Valley, as described below, a high landslide density correlates with relatively low-sloping areas of the valley floor that are covered by poorly consolidated sedimentary deposits.

360

\section{Langtang mass movements}

362

363

The earthquake-induced landslides of the Langtang Valley (Figs. 6, 7) were exceptional in their tragic results (over 350 killed) and are also among the Gorkha 
364 earthquake's best documented landslides from field- and space-based analysis. Langtang

365 Valley, $70 \mathrm{~km}$ north of Kathmandu, was one of Nepal's major trekking regions and

366 hosted benchmark glaciology, hydrology, and meteorology research (52-54). The valley

367 experienced moderate shaking (up to $\sim 0.26 \mathrm{~g}$ above Langtang village, Fig. 1B). An

368 analysis of post-event satellite imagery and oblique aerial photographs suggests that co-

369

370

371

372

373

374

375

376

377

378

379

380

381

382

383

384

385

386

387

388

389

390

391

392

393

394

395

396

397

398

399

400

401

402

403

404

405

406

407

408

409 seismic snow and ice avalanches and rockfalls and their massive concurrent air blasts contributed to the destruction in Langtang Valley (Figs. 6, 7, 8, 9, 10) that killed or left missing at least 350 people (55). Panoramic photos of Langtang taken in 2012 or rendered from pre-seismic scenes in Google Earth, and those taken after the earthquake on 12 May 2015 illustrate the magnitude and destruction of the Langtang events (Figs. 6, 7). Further indicating the vast scale of these events, annotated helicopter-borne photos and satellite imagery taken of the valley (Figs. 8, 9, 10) illustrate our interpretation of this disaster.

Fig. 6. Pre- and post-earthquake panoramic photos from the base of the cliff above Langtang village. Photos by D.F. Breashears/GlacierWorks

Debris from the initial co-seismic event covered $7.51 \times 10^{5} \mathrm{~m}^{2}$ (Fig. 6) at Langtang alone, including a $\sim 1 \mathrm{~km}$ stretch of the Langtang Khola (river). Stream impoundment was not observed in the days following the earthquake, thus indicating that meltwater and runoff tunneling rapidly cut through the icy deposit. Photos (D. Breashears) showed that the deposit contained large amounts of snow and ice. Melting resulted in the formation of ponds, moist debris, and cold surface temperature anomalies of the landslide (temperatures in the $270 \mathrm{~s} \mathrm{~K})$ relative to surrounding terrain $(280 \mathrm{~s}-290 \mathrm{~s} \mathrm{~K})$ according to the brightness temperatures derived from thermal band 10 of Landsat 8 on 30 April 2015 . At Langtang village, the primary coseismic event was a combined ice-snow avalanche, which initiated near $7000 \mathrm{~m}$. Subsequently, rockfall material was entrained with ice and snow and descended a low-gradient part of the glacier near $\sim 4500 \mathrm{~m}$. The rock-ice mass then became airborne as it fell off a cliff below $4500 \mathrm{~m}$ (Fig. 8). After the material reached the riverbed at $\sim 3250 \mathrm{~m}$, it ran up the opposing slope $\sim 200 \mathrm{~m}$ (Fig. 9). The air blasts propagated farther, $400 \mathrm{~m}$ up the mountain (Fig. 7). From the impact point on the valley floor, devastation extended $\sim 1 \mathrm{~km}$ up- and downvalley. From the $200 \mathrm{~m}$ high surge of debris on the opposing slope we estimate a debris speed $(v)$ of $63 \mathrm{~m} \mathrm{~s}^{-1}(227$ $\mathrm{km} \mathrm{h}^{-1}$ ) following Eq. 1:

$$
v=(2 g h)^{0.5}
$$

where $g$ is gravitational acceleration $\left(9.8 \mathrm{~m} \mathrm{~s}^{-2}\right)$, and $h$ is the runup. Landslide winds leveled what wasn't buried in Langtang, including some buildings constructed of stone slab; wind also completely flattened a small forest, thus suggesting wind speeds equivalent to an EF5 tornado (i.e., $>200 \mathrm{mph},>89 \mathrm{~m} / \mathrm{s},>322 \mathrm{~km} / \mathrm{h}$ wind speed), consistent with freefall drop of the landslide and heavily debris-laden wind over the cliff.

Satellite images provided by Digital Globe (e.g., Fig. 10) indicate a second large post-mainshock mass movement near Langtang village sometime before 25 May 2015. The source of this landslide may have been a rock detachment from the summit ridge of Langtang-Lirung,_ $6700 \mathrm{~m}$ elevation. The second landslide slightly increased the debris 
area from $7.51 \times 10^{5} \mathrm{~m}^{2}$ to $7.61 \times 10^{5} \mathrm{~m}^{2}$. At least one other large post-seismic landslide in the valley took place between 8-10 May 2015 .

Fig. 7: Destroyed Langtang. (A) Proximal landslide deposit (the landslide head) against steep slopes on the north side of Langtang. The sole surviving structure in Langtang was protected by the cliff (lower right of panel A). (B) Sole surviving structure has typical stone-slab construction on a foundation. (C, D) Distal (toe) part of the landslide. The Langtang River has tunneled beneath the landslide. The deposit flowed onto landslide wind-deposited debris, which has formed crevasses due to slumping toward the river. (E,F) Forest of small trees flattened by a powerful blast of debris-laden, landslide-driven wind. (G,H) Small post-seismic landslide and the wind-flattened forest. (I,J) Completely demolished wind-blasted part of Langtang. Panels E and F by Randall Jibson. Others by David Breashears (7 May 2015).

Nearby settlements of Singdum and Mundu (Fig. 10) were also damaged by air blasts from the Langtang Valley mass movements. The larger settlement of Kyangjin was also badly damaged by an air blast created by another avalanche that originated from the eastern ridge of Langtang-Lirung. Devastation in the air-blasted zones, as captured in several photos (Fig. 7) is indicative of the huge energy involved. The first Langtang landslide mass may be $\sim 3.3 \times 10^{9} \mathrm{~kg}$ (area $\sim 750,000 \mathrm{~m}^{2}$, assumed mean thickness $\geq 2 \mathrm{~m}$, density $2200 \mathrm{~kg} \mathrm{~m}^{-3}$ ). With a direct fall of $\sim 1 \mathrm{~km}$ the release of gravitational potential energy was $\geq 3.2 \times 10^{13} \mathrm{~J}$ (7.6-kiloton TNT equivalent). During freefall and impact, the main transfer of energy could only have been to the atmosphere and directly on the surface, the effects of which we sadly observed.

Fig. 8. Langtang's landslide flowpaths. The source areas and flow path of the two Langtang mass movements (white line, dashed where airborne). Red dashed line indicates the extent of the first slide; yellow dashed line indicates extent of second slide; purple dashed line indicates extent of debris run-up. West facing image. Stitched panorama from 10 May 2015; photos by D.F. Breashears/GlacierWorks.

Fig. 9. Extent of airblasts. West-facing aerial photo showing the extents of the air blast (dashed red line), the initial debris deposits and run-up (dashed purple line), and the secondary rockslide (dashed yellow line; photo 10 May 2015: D.F. Breashears/GlacierWorks).

Fig. 10. Satellite images of the upper Langtang Valley. (A) Area of Langtang village prior to the earthquake on 17 March 2011. (B) Same area on 3 May 2015, after the earthquake. (C) Overview image/map of the upper Langtang Valley on 25 May 2015, annotated with a key avalanche flow route (black line). Images courtesy of Digital Globe.

\section{Landslide blockages of rivers: Marsyangdi and Tom Khola rivers (Nepal) and Gyirong Zangbo/Trishuli River (Tibet)}

Recurrent landslides were identified along the upper Marsyangdi River in the Annapurna region. These are a different type of landslide than present in Langtang Valley. At least twenty mass movements intersected the river in the 10 days following the main shock (Fig. 11). The rapid sequence of similar failures demonstrates that the quakes in some way disturbed the unconsolidated sediments (36) along the river, perhaps by altering the hydrology or opening soft-sediment fractures, which then were exploited by spring seepage/erosion and rotational failures. 
The Marsyangdi Valley experienced relatively weak shaking (to $\sim 0.13 \mathrm{~g}$, Fig. 1B, Table S3), which triggered nine small landslides along a 16-km stretch of the upper Marsyangdi River between Humde and Bratang (Fig. 11). The landslides were identified from a WorldView-2 satellite image 27 April 2015, two days after the earthquake, but were not present in a Landsat 8 image four days pre-quake; thus, they are considered primary effects of the main shock. Some slumps constricted but did not greatly obstruct the river. One landslide (Fig. 11) 2.2 km upstream of Lower Pisang village caused a small impoundment $\left(135 \mathrm{~m}\right.$ long, $\left.\sim 2 \times 10^{3} \mathrm{~m}^{2}\right)$.

Between 27 April and 2 May 2015, five more landslides reached the river, including one $\sim 200 \mathrm{~m}$ wide, which caused a complete blockage $\sim 1.9 \mathrm{~km}$ upstream of Lower Pisang. The impoundment grew to $\sim 550 \mathrm{~m}$ long and $30-40 \mathrm{~m}$ wide $\left(\sim 1.4 \times 10^{4}\right.$ $\mathrm{m}^{2}$ ) (Fig. 11). Six new landslides upstream then increased the lake to $\sim 2.5 \times 10^{4} \mathrm{~m}^{2}$ and $1100 \mathrm{~m}$ long, the same as measured again on 28 May 2015. Upstream, several smaller impoundments indicated a further hazardous situation where a dam breach could initiate a succession of lower dam breaches and the inundation of Lower Pisang village.

Ground photographs (Fig. 11B) show a predominantly fine-grained landslide, likely composed of fluvial gravels and lacustrine silts from former dammed lakes (36). The steep headwall, back-tilted trees, and a sharp detachment at the head of the landslide indicate that the slide is a rotational slump, a common failure mode in poorly supported, unconsolidated sediments.

The appearance of eleven post-main-shock landslides and growth of the impoundment lake represent secondary and tertiary effects of the earthquake and indicate that the region is susceptible to long-term slope instability and future landslides.

Many other cases of earthquake-induced landslide blockages of rivers occurred. In one case, a $450 \mathrm{~m}$-wide landslide blocked the lower Tom Khola (river) near Ghap, Manaslu Conservation Area, Nepal, creating an impoundment lake that stirred urgent humanitarian concerns. Satellite imagery from 3, 5, 7 and 8 May have allowed monitoring of the dammed lake. Between 3 and 8 May, the lake grew from $\sim 5.7 \times 10^{4} \mathrm{~m}^{2}$ to $\sim 6.6 \times 10^{4} \mathrm{~m}^{2}$. The nearby village of Ghap, located downstream of the confluence of the Tom Khola and Budhi Gandaki rivers, fortunately showed no flood damage by 16 May, indicating that even though the lake was draining through a narrow outlet, the dam erosion was gradual. A satellite image from 8 June and subsequent media coverage shows that most of the lake had drained without severe consequences.

The Gorkha earthquake and its many aftershocks also triggered dozens of landslides into the south-flowing Gyirong River, China (= Trishuli River downstream in Nepal). One landslide dammed the river $\sim 1.5 \mathrm{~km}$ south of Chongsecun, a few kilometers north of the Nepalese border, causing development of a $450 \times 50 \mathrm{~m}$ impoundment lake $(28.363 \mathrm{~N}, 85.360 \mathrm{E}, \sim 2,600 \mathrm{~m}$ asl). The landslide destroyed $\sim 200 \mathrm{~m}$ of the road that connected Chongsecun to the China-Nepal border crossing at Resuo. Boulders and debris were displaced downslope, forming a landslide scar $\sim 700 \mathrm{~m}$ long and a deposit $250 \times 300$ $\mathrm{m}$. Several landslides and a landslide-dammed lake also developed south of the Chongsecun slide on or near the Resuo border crossing in Nepal (28.275N, 85.379E, $\sim 1,810 \mathrm{~m}$ asl) and blocked the road near the Resuo bridge. A field reconnaissance team from the Chinese Ministry of Land and Resource visited the Resuo landslide on 4-5 May 2015 and estimated the landslide deposit to be $\sim 2.7 \times 10^{6} \mathrm{~m}^{3}$. This ranks it as the Chinese side's largest landslide of the Gorkha earthquake and aftershocks. Fortunately, the dam 
was incised by the river, and with mitigation efforts by engineers there was no further

503 damage.

Another landslide on the same river near Resuo was triggered by a rainstorm on 28 April 2015, with the terrain conditioned by the M7.8 Gorkha earthquake. The landslide dammed the Trishuli Khola (river) and blocked the road from Gyirong County to Resuo Port.

Due to these landslides, residents north of the border were trapped, unable to

Fig. 11. Landslide-dammed lake on the Marsyangdi River. Map and satellite imagery and ground photographs of landslides and landslide-dammed lakes on upper Marsyangdi River. (A) Map. White box locates panels C, D, E, and F. (B) Ground photograph (courtesy Mukhya Gotame, Manang villager) from 10 May 2015, showing the landslide-dammed lake looking south. White dashed line is the head scarp (note steep headwall) and curved arrow shows inferred flow path of the rotational slump. (C,D,E,F): Highresolution WorldView-2 images of the river, showing delayed occurrence of the large landslide and lake formation. White star in D locates panel B. River widths are given at two locations.

Fig. 12. Lake survey for earthquake damage. Upper panel A) Overview of study area showing location of 491 surveyed lakes. Lower panels B-J) pre-earthquake images (right column), post-main shock images (center column) and post-12 May aftershock images (left column) for the largest glacial lakes in Nepal, BD), Thulagi Lake, E-G) Tsho (Lake) Rolpa, H-J) Imja Tsho. B) Landsat 8 image of Thulagi Lake, 21 April 2015. C) Worldview 2 image of Thulagi Lake, 27 April 2015. D) ASTER image of Thulagi Lake, 22 May 2015. E) Landsat 8 image of Tsho Rolpa, 11 November 2013. F) Worldview 1 image of Tsho Rolpa, 4 May 2015. G) EO-1 ALI image of Tsho Rolpa 17 May 2015. H) Landsat 8 image of Imja Tsho, 11 November 2013. I) EO-1 ALI image of Imja Tsho, 28 April 2015. J) Landsat 8 image of Imja Tsho, 25 May 2015. A large crack developed in the lake ice on Imja Tsho, though such cracks are normal with spring thaw. Landsat 8 scenes are panchromatic-band-8-sharpened images (resolution $15 \mathrm{~m}$ ) using band combinations [7,5,3] (SWIR, NIR, Green). WorldView 2 false color composite scene uses band combination [7, 5, 3] (NIR, Red, Green). WorldView 1 image is the panchromatic band. ASTER image (resolution $15 \mathrm{~m}$ ) uses bands [3N, 2, 1] (NIR, Red, Green). EO-1 ALI scenes use pan-sharpened band 1 (resolution $10 \mathrm{~m}$ ) and band combination $[8,6,4]$ (SWIR, NIR, Green).

550

\section{Glacier lakes stability}

Many glacial lake outburst floods (GLOFs) have been recorded in the Himalaya since the mid-20th century (56). It is widely considered that the lakes' moraine damscommonly situated at the angle of repose - are fragile and prone to outburst due either to sudden collapse or piping erosion, or to gradual degradation due to climatic warming and thaw. Avalanche/landslide-generated displacement waves are thought to be a common trigger for moraine dam failure (57). Thus, when the largest earthquakes happened, we and many experts were concerned that shaking may have weakened or collapsed 
551

552

553

554

555

556

557

558

559

560

561

562

563

564

565

566

567

568

569

570

571

572

573

574

575

576

577

578

579

580

581

582

583

584

585

586

587

588

589

590

591

592

593

594

595

596 unconsolidated moraine dams of glacial lakes, or may have triggered large displacement waves and GLOFs.

Fortunately, few earthquake effects on glacier lakes were identified. We examined pre- and post-quake satellite images of 491 lakes (locations drawn mainly from the inventory of Fujita et al. (58)). Only nine were physically hit by landslides or avalanches. Of these, ice avalanches may have ejected water from two small ponds near Everest, and debris fell onto the frozen surfaces of other lakes without further effect. To our knowledge, as of early September 2015 no lakes in the satellite survey produced a GLOF as a result of the earthquake. GLOFs were primarily not triggered at modeled PGAs up to $0.57 \mathrm{~g}$ (Fig. 2D). This unexpected result may relate to seismic wave interactions with the topography, where, for shallow hypocenters, PGAs (i) are reduced on valley floors, and (ii) are rapidly reduced by shielding across mountain ranges caused by wave scattering on the topography and petrologic structure $(51,59)$. The visibility of 15 lakes in our database was unclear (partially shadowed or poor resolution image) but their downstream drainages showed no signs of GLOFs.

Furthermore, we closely examined three large moraine-dammed glacial lakes (Thulagi, Rolpa, and Imja, Fig. 12), which have been extensively surveyed, studied, and monitored due to their GLOF risk (e.g., 56). At Thulagi Lake in the Manaslu region (just west of the Tom Khola (river) blockage described above) and Imja Lake in the Everest region, no damage was immediately evident in post-quake satellite imagery. However, based on local media and a Sherpa leader, a small glacial lake south of Everest, apparently a pond on Lhotse Glacier, drained on 27 May 2015, which resulted in an anomalous rise in stream level. Small supraglacial ponds commonly drain suddenly due to ice fracturing or other glacier dynamics, and it is unclear if this event was earthquakerelated. Besides the 491 lakes for which we have some kind of satellite observation, 24 other lakes had no clear image and so are unsurveyed.

Fig. 13. Field visit identifies light damage at Tsho (lake) Rolpa. (A) Post-earthquake image of Tsho Rolpa appears identical to its appearance shortly before the earthquake. (B) Two areas of fractures (outlined in white) - believed formed by the 12 May 2015 aftershock- were observed on the engineered part of the end moraine from a helicopter during an inspection undertaken by the U.S. Geological Survey at Tsho Rolpa. Photos from 27 May by Brian Collins (USGS), courtesy of USAID-OFDA (Office of Foreign Disaster Aid).

Tsho Rolpa, located at the terminus of Trakarding Glacier in the Rolwaling Valley, has been especially worrisome due to its location near the giant aftershock's epicenter. Examination of WorldView 1 satellite images taken on 4 May - nine days after the initial earthquake, and the NASA's EO-1 satellite image taken 17 May-five days after the M7.3 aftershock - shows no definitive evidence that Tsho Rolpa's damming moraine was damaged. Post-quake field photographs taken by the USGS on 27 May show that the moraine was intact, and the lake was nearly brim full, as usual (Fig. 13A). Another USGS photograph (Fig. 13B) shows fractures on the moraine dam-but not of a type likely to be a problem. Since no ice exists in this part of the moraine, these cracks appear to have been caused by slumping of moraine material toward the lake (1-1.5 m horizontal and $\sim 0.5 \mathrm{~m}$ vertical), probably due to earthquake. The satellite imagery and field photographs do not demonstrate any new big additional concerns about the lake. 
A caveat is that a small GLOFs and minor damage to moraines would not be visible in satellite images. Furthermore, none of the methods applied to date-satellite and ground or helicopter-borne inspections - can easily detect interior (subsurface) structural damage that may make the metastable lakes even more subject to outburst. "Absence of evidence is not evidence of absence," a controversial quote made famous by Carl Sagan, is clearly pertinent to our absent evidence of significant Gorkha earthquake damage to lakes. We simply have not seen such evidence but cannot conclude that there is no damage.

\section{Future Gorkha-earthquake-related landslides}

In coming years, hydrological processes may exploit earthquake-induced damage and trigger more landslides (e.g., frost shattering and rockfalls at high elevations, riverbank undercutting and rotational slumping in valleys). Conversely, high-magnitude shaking-induced landslides, such as ridgetop failures that affected Langtang Valley, may be less significant, unless additional strong aftershocks strike or unless high-elevation melting takes place within seismically shattered rocks. However, earthquake-related landslides will soon fade into the regional background frequency of landslide activity.

The incidence of landsliding was less for this earthquake than for some comparable quakes elsewhere, and no large GLOFs were generated. Whether the same will hold for a hypothetical future large Himalayan earthquake is uncertain. However, future earthquakes generated on the shallow Main Himalayan Thrust are not apt to generate many or any GLOFs unless the magnitude is greater than the Gorkha earthquake's or the hypocenter and zone of maximum slip is closer to the lakes, thus circumventing the shielding by Himalayan relief. Ridgetop shattering is probably a general behavior during big earthquakes. The potential exists for immense landslides and river blockages, which may pose the greatest mountain hazard.

\section{Summary and Conclusions}

Our rapid, systematic mapping allowed us to investigate earthquake-induced geohazard processes and provide information to relief and recovery officials on the same timeframe as those operations were occurring. This work thus contributed to effective, timely guidance to in-country authorities responsible for response and recovery. Key findings were relayed through NASA, USGS, and the U.S. Agency for International Development, and to Nepal-based experts at ICIMOD (International Centre for Integrated Mountain Development) and DHM (Department of Hydrology and Meteorology, Government of Nepal) and to the Nepal Prime Minister.

The mapped features document the large geographic extent of the Gorkha earthquake's impact on hazardous Earth surface processes and constrain their geophysical limits and geomorphic, tectonic and geologic controls. The distribution of induced landslides shows positive associations with slope and shaking intensity. More broadly the highest areal densities of landslides are developed primarily on the downdropped northern tectonic block. This might be explained by momentary reduction during downward acceleration of the normal stress along planes of weakness. The largest two shocks are bookends on the landslide distribution, as they are with the displacement field and highest PGAs. Additional controls of landslide distribution are indicated by their 
642 clustering within specific bedrock and surficial lithologies including Proterozoic

643 metamorphic rocks and Ordovician granitoids; in proximity to earthquake epicenters;

644 with high PGAs; and perhaps with seismic wave scattering and interferences.

645

646

647

In the remote valleys of the higher Himalaya, the most concentrated losses were

648

649

650

651

652

653

654

655

656

657

658

659

660

661

662

663

664

665

666

667

\section{Data Availability} directly due to the induced mass movements and air blasts rather than shaking. Complex seismic wave interactions may have contributed to destruction in Langtang Valley and other locations due to wave focusing and ridgetop shattering but may have reduced direct shaking damage in valley floors and at glacial lakes.

The distribution of Gorkha earthquake-related landslides and the terrain susceptibilities to earthquake-induced mass movements provides a basis from which to predict future patterns of landsliding of earthquake-weakened ice, rock, and unconsolidated sediments, especially as aftershocks and precipitation and snowmelt events continue over the next few years. Whereas the Gorkha earthquake's tragic toll on human lives and culture cannot be understated, some fortunate facts are that not a single major GLOF was unleashed and the total number of landslides was far fewer than generated by comparable earthquakes (56).

668

669

670

671

672

673

674

675

676

677

678

679

680

681

682

683

684

685

686

\section{Acknowledgements}

The two chief databases produced by this work (landslides and glacial lakes) will be redundantly available, immediately upon publication, at two web portals, one at ICIMOD and one at Marshall Space Flight Center.

JSK, GJL, and UKH thank the NASA SERVIR Applied Science Team and NASA Cryosphere Program for support. DHS thanks the Hakai Institute for support. Part of this research was sponsored by the NASA Earth Surface and Interior focus area and performed at the Jet Propulsion Laboratory, California Institute of Technology. We gratefully acknowledge support from several "citizen scientists" who provided key observations and reports from various locations in Nepal: Deep Rai, JB Rai, Nabaraj Sapkota, Mauli Dhan Rai, and Mukhya Gotame, who made on-site inspections and photo documentation of Thulagi (Dona) Lake, Rolpa Lake, Kali Gandaki, and 'Lower Pisang' landslide dammed lake. ASTER data courtesy of NASA/GSFC/METI/Japan Space Systems, the U.S./Japan ASTER Science Team, and GLIMS. We especially laud DigitalGlobe's decision to acquire and make available a vast volume of data for analysis related to Gorkha earthquake response. We thank Cunren Liang for processing the ALOS-2 wide-swath interferogram. Original ALOS-2 data are (C) 2015 JAXA. This study was partially supported by core funds of ICIMOD contributed by the governments of Afghanistan, Australia, Austria, Bangladesh, Bhutan, China, India, Myanmar, Nepal, Norway, Pakistan, Switzerland, and the United Kingdom. 


\section{References}

688 1. R. M. Parameswaran et al., Seismotectonics of the April-May 2015 Nepal

689 earthquakes: An assessment based on the aftershock patterns, surface effects and

690 deformational characteristics. J. Asian Earth Sci. 111, 161-174 (2015).

691 2. J. Galetzka et al., Slip pulse and resonance of the Kathmandu basin during the

692

693

694

695

696

697

698

699

700

701

702

703

704

705

706

707

708

709

710

711

712

713

714

715

716

717

718

719

720

721

722

723

724

725

726

727

728

729

730 2015 Gorkha earthquake, Nepal. Science 349, 1091-1095 (2015).

3. E. O. Lindsey et al., Line-of-sight displacement from ALOS-2 interferometry: Mw7.8 Gorkha Earthquake and Mw7.3 aftershock. Geophys. Res. Lett. 42, 66556661 (2015).

4. K. Jaiswal, D. Wald, D. D'Ayala, Developing empirical collapse fragility functions for global building types. Earthquake Spectra 27, 775-795 (2011).

5. J. S. Kargel, G. J. Leonard, M. P. Bishop, A. Kääb, B. H. Raup, Global Land Ice Measurements from Space. (Springer-Verlag, Berlin Heidelberg, 2014).

6. E. L. Harp, D. K. Keefer, H. P. Sato, H. Yagi, Landslide inventories: The essential part of seismic landslide hazard analyses. Eng. Geol. 122, 9-21 (2011).

7. J. A. N. van Aardt et al., Geospatial disaster response during the Haiti earthquake: A case study spanning airborne deployment, data collection, transfer, processing, and dissemination. Photogr. Eng. Rem. Sens. 77, 943-952 (2011).

8. G. Cecchine et al., "The U.S. Military Response to the 2010 Haita Earthquake Considerations for Army Leaders," (RAND Corporation, 2013).

9. H. P. Sato, E. L. Harp, Interpretation of earthquake-induced landslides triggered by the 12 May 2008, M7.9 Wenchuan earthquake in the Beichuan area, Sichuan Province, China using satellite imagery and Google Earth. Landslides 6, 153-159 (2009).

10. M. R. Yoder, J. B. Rundle, M. T. Glasscoe, Near-field ETAS constrains and applications to seismic hazard assessment. Pure Appl. Geophys., 2277-2293 (2014).

11. R. N. Parker et al., Mass wasting triggered by the 2008 Wenchuan earthquake is greater than orogenic growth. Nature Geosci. 4, 449-452 (2011).

12. C. Xu, X. Xu, X. Yao, F. Dai, Three (nearly) complete inventories of landslides triggered by the May 12, 2008 Wenchuan Mw 7.9 earthquake of China and their spatial distribution statistical analysis. Landslides 11, 441-461 (2014).

13. R. M. Yuan et al., Density distribution of landslides triggered by the 2008 Wenchuan earthquake and their relationships to peak ground acceleration. Bull. Seism. Soc. Am. 103, 2344-2355 (2013).

14. E. L. Harp et al., Landslides and liquefaction triggered by the M 7.9 Denali Fault earthquake of 3 November 2002. GSA Today August, 4-10 (2003).

15. R. W. Jibson, E. L. Harp, W. Schulz, D. K. Keefer, Landslides triggered by the 2002 Denali fault, Alaska, earthquake and the inferred nature of the strong shaking. Earthquake Spectra 20, 669-691 (2004).

16. D. H. Shugar, J. J. Clague, The sedimentology and geomorphology of rock avalanche deposits on glaciers. Sedimentology 58, 1762-1783 (2011).

17. F. C. Dai et al., Spatial distribution of landslides triggered by the $2008 \mathrm{Ms} 8.0$ Wenchuan earthquake, China. J. Asian Earth Sci. 40, 883-895 (2011). 
731

732

733

734

735

736

737

738

739

740

741

742

743

744

745

746

747

748

749

750

751

752

753

754

755

756

757

758

759

760

761

762

763

764

765

766

767

768

769

770

771

772

773

774

775

18. D. H. Shugar, B. T. Rabus, J. J. Clague, D. M. Capps, The response of Black Rapids Glacier, Alaska, to the Denali earthquake rock avalanches. J. Geophys. Res. 117, F01006 (2012).

19. S. G. Evans et al., Catastrophic detachment and high-velocity long-runout flow of Kolka Glacier, Caucasus Mountains, Russia in 2002. Geomorphology 105, 314321 (2009).

20. W. Haeberli et al., The Kolka-Karmadon rock/ice slide of 20 September 2002: an extraordinary event of historical dimensions in North Ossetia, Russian Caucasus. J. Glaciol. 50, 533-546 (2004).

21. J. S. Kargel et al., Satellite monitoring of Pakistan's rockslide-dammed Lake Gojal. EOS, Trans. AGU 91, 394-395 (2010).

22. V. Vilimek, M. L. Zapata, J. Klimes, Z. Patzelt, N. Santillán, Influence of glacial retreat on natural hazards of the Palcacocha Lake area, Peru. Landslides 2, 107115 (2005).

23. M. Carey, Living and dying with glaciers: people's historical vulnerability to avalanches and outburst floods in Peru. Global Planet. Change 47, 122-134 (2005).

24. S. A. Dunning, N. J. Rosser, D. N. Petley, C. R. Massey, Formation and failure of the Tsatichhu landslide dam, Bhutan. Landslides 3, 107-113 (2006).

25. J. T. Weidinger, in Natural and Artificial Rockslide Dams, S. G. Evans, R. L. Hermanns, A. Strom, G. Scarascia-Mugnozza, Eds. (Springer, Berlin Heidelberg, 2011), pp. 243-277.

26. M. Geertsema, J. J. Clague, Pipeline routing in landslide-prone terrain. Innovations July/August, 17-21 (2011).

27. K. Hewitt, Disturbance regime landscapes: mountain drainage systems interrupted by large rockslides. Prog. Phys. Geog. 30, 365-393 (2006).

28. Materials and methods are available as supplementary materials on Science Online.

29. Y. Ogata, Statistical models for earthquake occurrences and residual analysis for point processes. J. Am. Stat. Assn. 83, 9-27 (1988).

30. D. K. Keefer, Investigating landslides caused by earthquakes - A historical review. Surv. Geophys. 23, 473-510 (2002).

31. C. Xu, X. Xu, J. B. H. Shyu, Database and spatial distribution of landslides triggered by the Lushan, China Mw 6.6 earthquake of 20 April 2013. Geomorphology 248, 77-92 (2015).

32. A. Jarvis, H. I. Reuter, A. Nelson, E. Guevara, Hole-filled seamless SRTM data v4 (available at http://srtm.csi.cgiar.org). (International Centre for Tropical Agriculture (CIAT), 2008).

33. P. Meunier, N. Hovius, J. A. Haines, Topographic site effects and the location of earthquake induced landslides. Earth Planet. Sci. Lett. 275, 221-232 (2008).

34. A. Arendt et al., "Randolph Glacier Inventory - A Dataset of Global Glacier Outlines: Version 4.0," (Global Land Ice Measurements from Space, Boulder, CO, 2014).

35. U.S. Geological Survey, Earthquake Hazards Program (available from http://earthquake.usgs.gov). (2015). 
776

777

778

779

780

781

782

783

784

785

786

787

788

789

790

791

792

793

794

795

796

797

798

799

800

801

802

803

804

805

806

807

808

809

810

811

812

813

814

815

816

817

818

819

820

821

36. J. T. Weidinger, Predesign, failure and displacement mechanisms of large rockslides in the Annapurna Himalayas, Nepal. Eng. Geol. 83, 201-216 (2006).

37. H. T. Chou, C. F. Lee, S. C. Chen, in Earthquake-Induced Landslides: Proceedings of the International Symposium on Earthquake-Induced Landslides, K. Ugai, H. Yagi, A. Wakai, Eds. (2013), pp. 45-57.

38. L. Chen et al., Liquefaction macrophenomena in the great Wenchuan earthquake. Earthquake Eng. and Eng. Vibra. 8, 219-229 (2009).

39. P. L. Moore, N. R. Iverson, D. Cohen, Ice flow across a warm-based/cold-based transition at a glacier margin. Ann. Glaciol. 50, 1-8 (2009).

40. H. Blatter, G. K. C. Clarke, J. Colinge, Stress and velocity fields in glaciers: Part II. Sliding and basal stress distribution. J. Glaciol. 44, 457-466 (1998).

41. N. Bo, J. Persson, in Sliding on Ice and Snow: Physical Principles and Applications. (Springer, Berlin, 1998), pp. 391.

42. P. Deline et al., in Snow and Ice-Related Hazards, Risks and Disasters, W. Haeberli, C. Whiteman, J. F. Shroder, Eds. (Elsevier, Amsterdam, 2015), pp. 521561.

43. M. Geertsema, M. Chiarle, in Treatise on Geomorphology, J. F. Shroder, M. Stoffel, R. A. Marston, Eds. (Elsevier, Amsterdam, 2013), vol. 7: Mountain and Hillslope Geomorphology, pp. 217-222.

44. R. W. Jibson, E. L. Harp, "Field reconnaissance report of landslides triggered by the January 12, 2010, Haiti earthquake," (U.S. Geological Survey Open-File Report 2011-1023, Reston, VA, 2011).

45. E. L. Harp, R. W. Jibson, Landslides triggered by the 1994 Northridge, California earthquake. Bull. Seism. Soc. Am. 86, S319-S332 (1996).

46. J. Stöcklin, Geology of Nepal and its regional frame. J. Geol. Soc. London 137, 134 (1980).

47. M. R. Dhital, Geology of the Nepal Himalaya. Regional Geology Reviews (Springer, 2015).

48. L. S. Walsh, A. J. Martin, T. P. Ojha, T. Fedenczuk, Correlations of fluvial knickzones with landslide dams, lithologic contacts, and faults in the southwestern Annapurna Range, central Nepalese Himalaya. J. Geophys. Res. 117, F01012 (2012).

49. B. D. Collins, R. W. Jibson, "Assessment of existing and potential landslide hazards resulting from the April 25, 2015 Gorkha, Nepal earthquake sequence," (U.S. Geological Survey Open-File Report 2015-1142, Reston, VA, 2015).

50. R. S. Stein, G. C. P. King, J. Lin, Stress triggering of the $1994 \mathrm{M}=6.7$ Northridge, California, earthquake by its predecessors. Science 265, 1432-1435 (1994).

51. S.-J. Lee, D. Komatitsch, B.-S. Huang, J. Tromp, Effects of topography on seismic-wave propagation: an example from northern Taiwan. Bull. Seism. Soc. Am. 99, 314-325 (2009).

52. W. W. Immerzeel, L. Petersen, S. Ragettli, F. Pellicciotti, The importance of observed gradients of air temperature and precipitation for modeling runoff from a glacierized watershed in the Nepalese Himalayas. Water Res. Res. 50, 22122226 (2014).

53. K. Fujita, T. Nuimura, Spatially heterogeneous wastage of Himalayan glaciers. Proc. Natl. Acad. Sci. 108, 14011-14014 (2011). 
822 54. S. Ragettli et al., Unraveling the hydrology of a Himalayan catchment through

823

824

825

826

827

828

829

830

831

832

833

834

835

836

837

838

839

840

841

842

843

844

845

846

847

848

849

850

851

852

853

854

855

856

857

858

859

860

861

862

863

864

865

866

867

868

869

870

871

872 integration of high resolution in situ data and remote sensing with an advanced simulation model. Adv. Wat. Resour. 78, 94-111 (2015).

55. C. Cadwalladr, Nepal earthquake: the village wiped off the map in a few terrifying seconds. (The Guardian, 2015).

56. ICIMOD, Glacial Lakes and Glacial Lake Outburst Floods in Nepal. (International Centre for Integrated Mountain Development, Kathmandu, Nepal, 2011), pp. 99.

57. J. J. Clague, S. G. Evans, A review of catastrophic drainage of moraine-dammed lakes in British Columbia. Quat. Sci. Rev. 19, 1763-1783 (2000).

58. K. Fujita et al., Potential flood volume of Himalayan glacial lakes. Nat. Haz. Earth Sys. Sci. 13, 1827-1839 (2013).

59. S. Ma, R. J. Archuleta, M. T. Page, Effects of large-scale topography on ground motions as demonstrated by a study of the San Gabriel Mountains, Los Angeles, California. Bull. Seism. Soc. Am. 97, 2066-2079 (2007). 
873

874
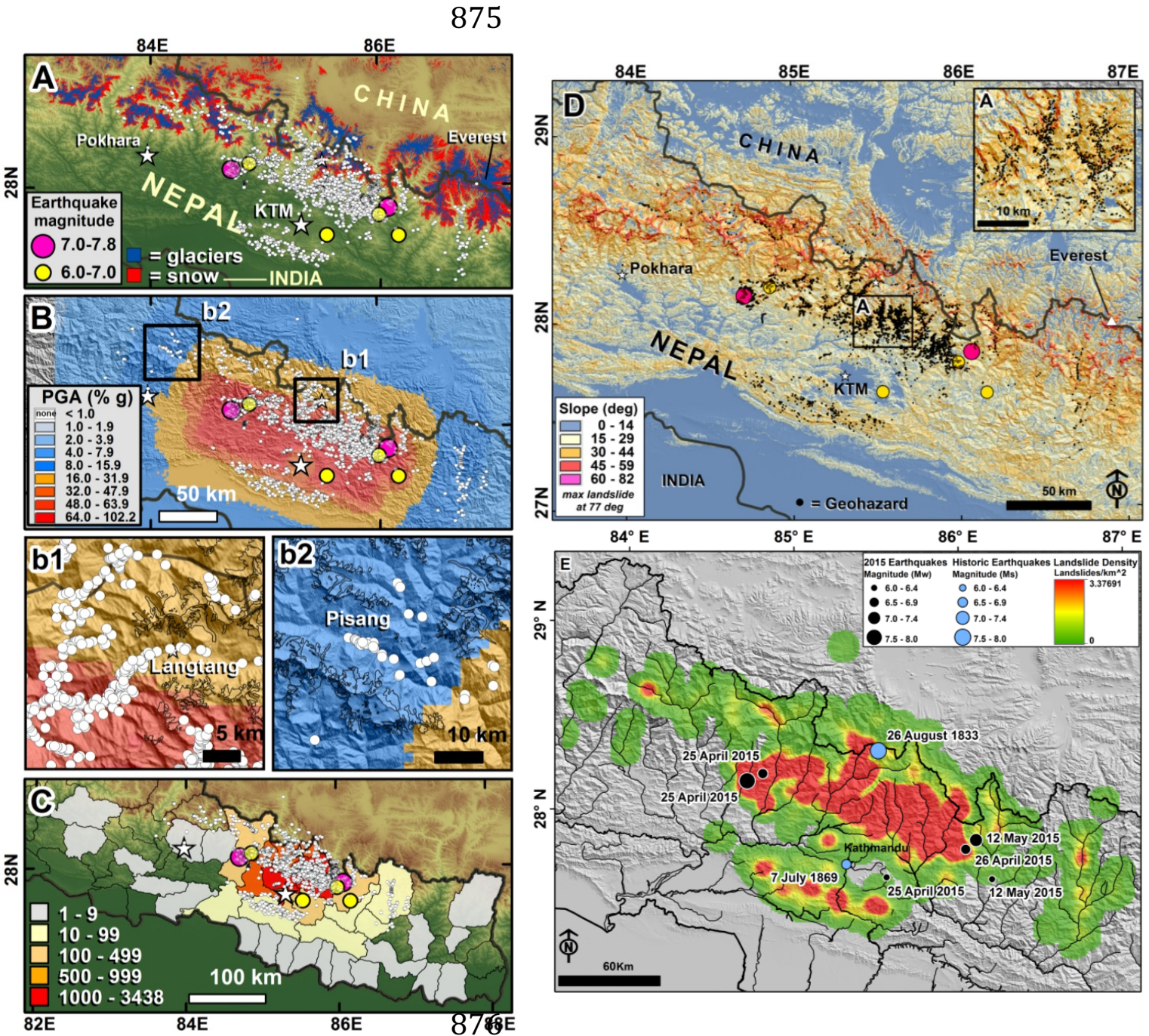

877

878

879

Fig. 1.

880

881

882

883

884

885

886

887

888

889

890

891

892

893

894

895 

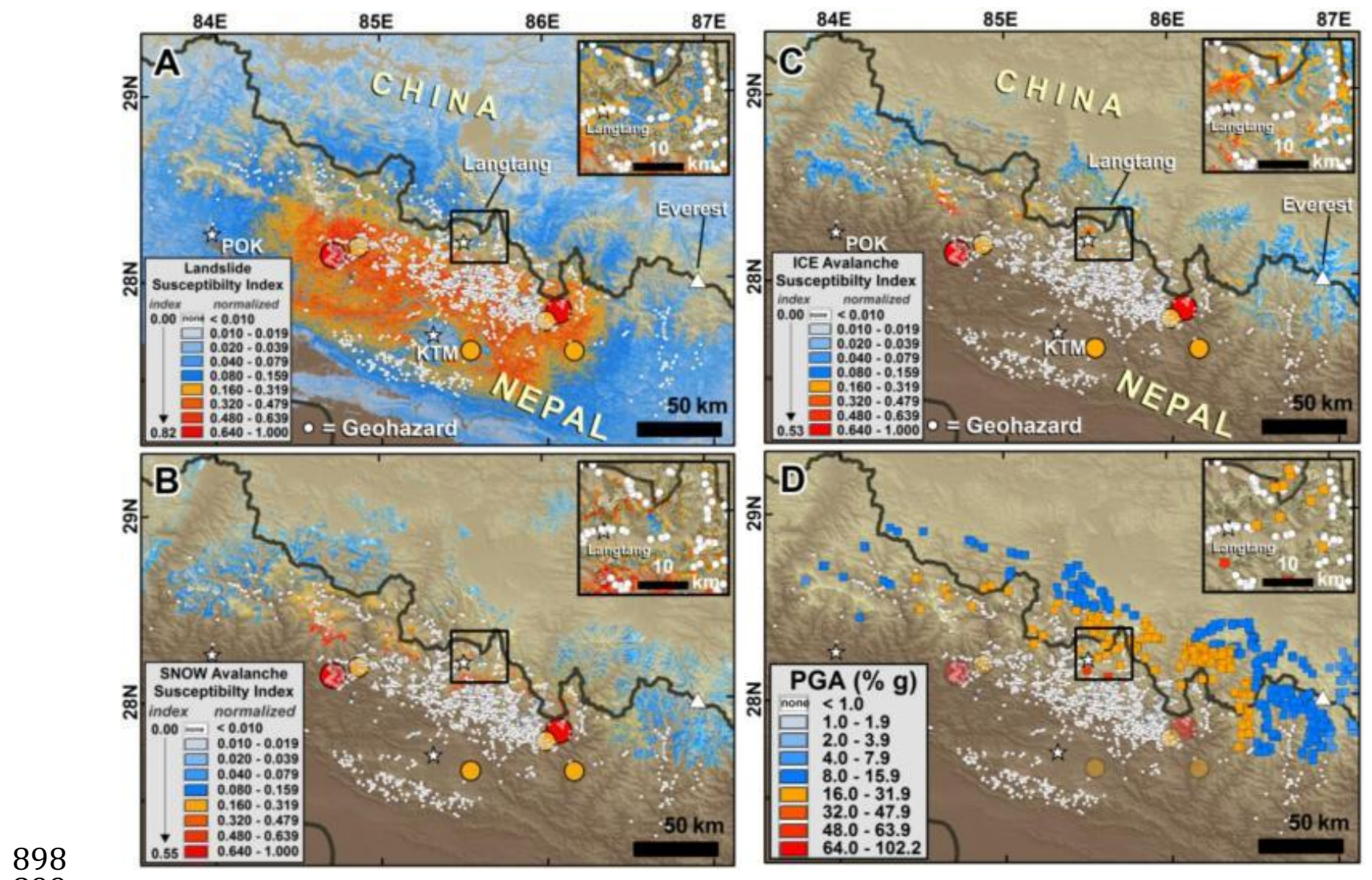

899

900

Fig. 2.

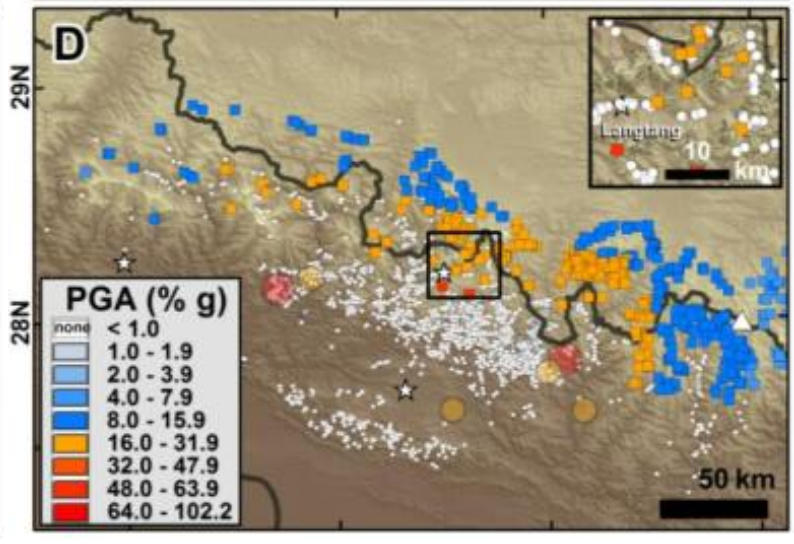

901

902

903

904

905

906

907

908

909

910

911

912

913

914

915

916

917 

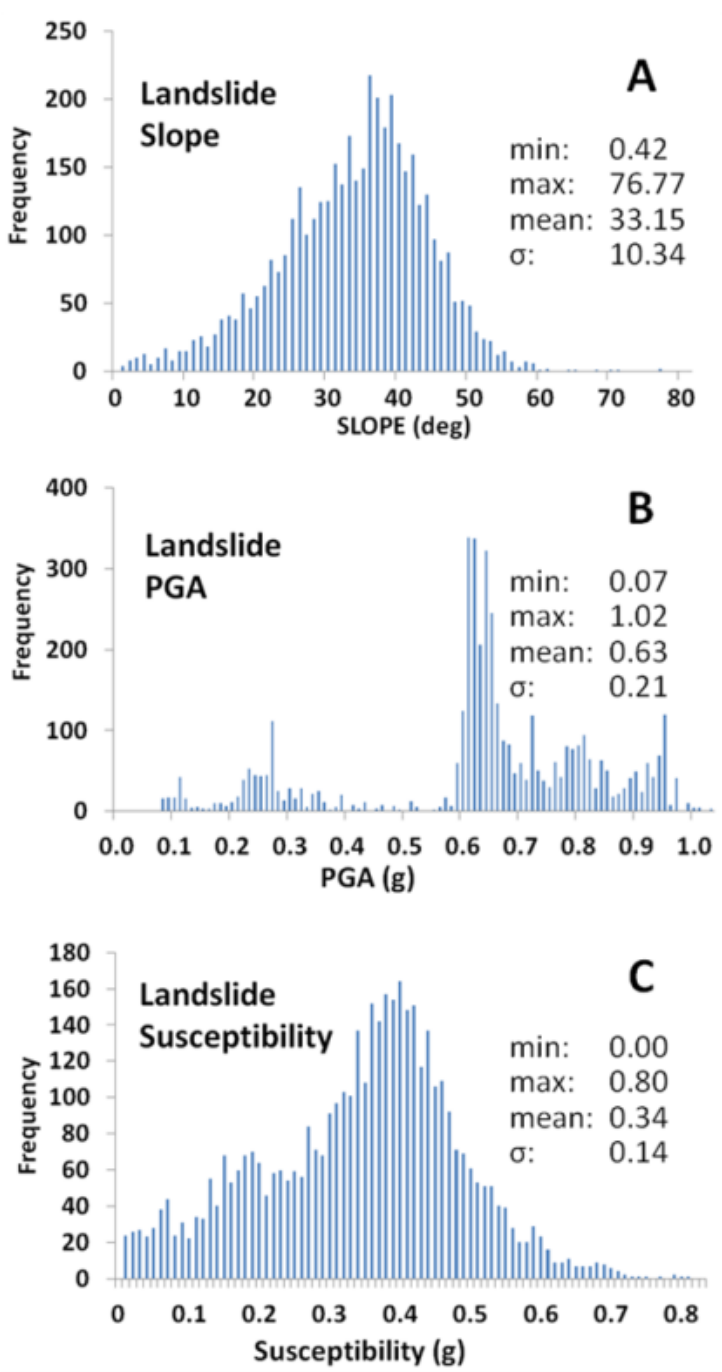
Susceptibility (g)

Fig. 3. 

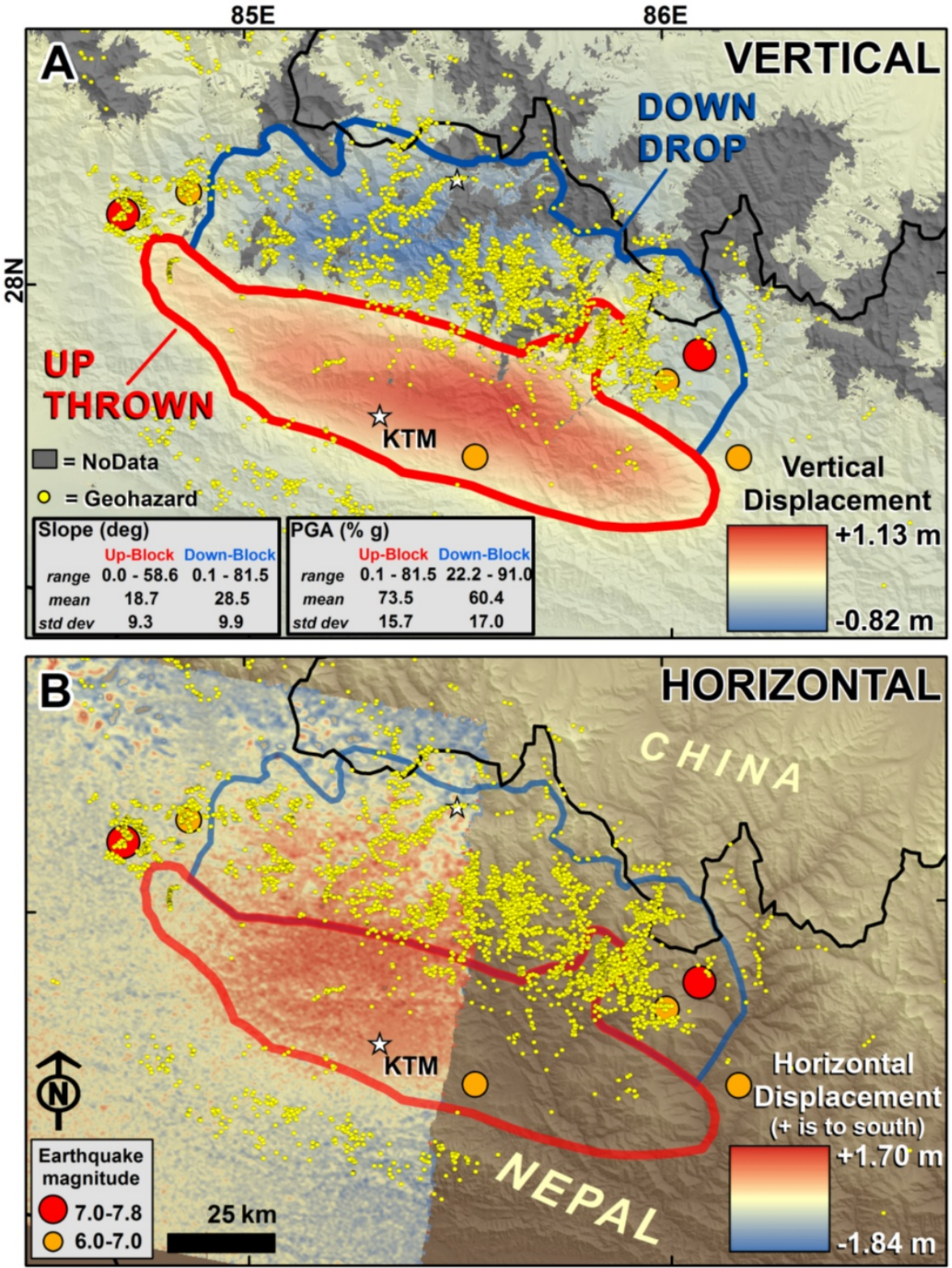

941 Fig. 4.

942

943

944

945

946

947

948

949

950 


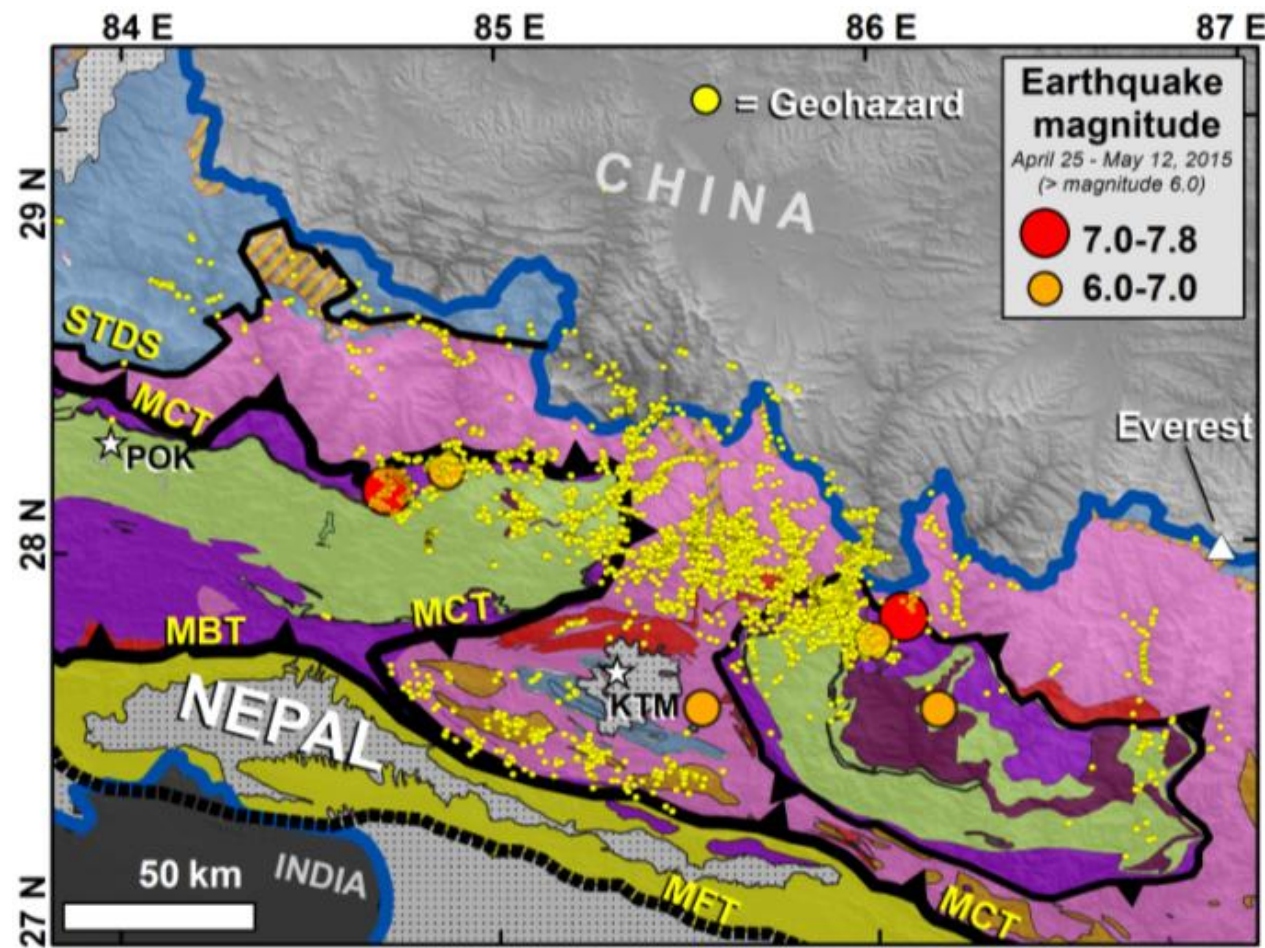

Intermontane basin fill Siwalik sediments

Lesser Himalaya (Proterozoic)

$\square$ phyllite, amphibolite, metasandstone, schist, quartzite slate, shale, siltstone, sandstone, graphitic schist, carbonate bands

gneiss, minor syenite
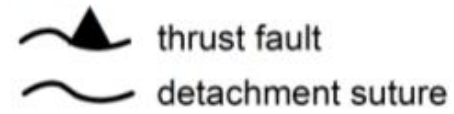

Tethyan Himalaya (Paleo-Mesozoic) marine / continental shelf sediments (limestone, shale, sandstone)

High Himalaya Crystal.(Proterozoic)

$\square$ schist, quartzite, gneiss gneiss

two-mica leucogranite (Miocene) granite (Paleozoic)

Fig. 5. 

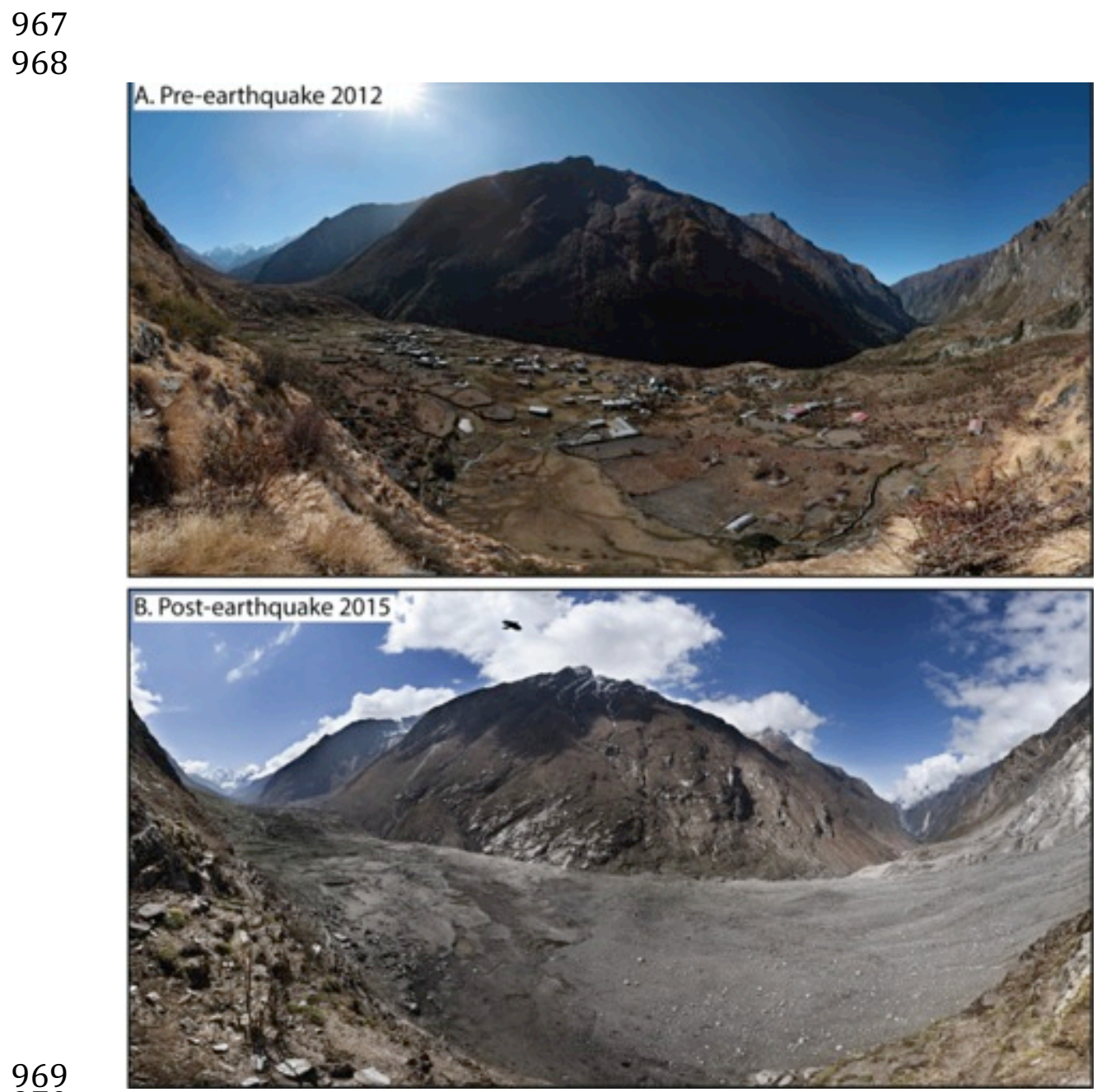

970

Fig. 6.

971

972

973

974

975

976

977

978

979

980

981

982

983

984

985

986

987

988 

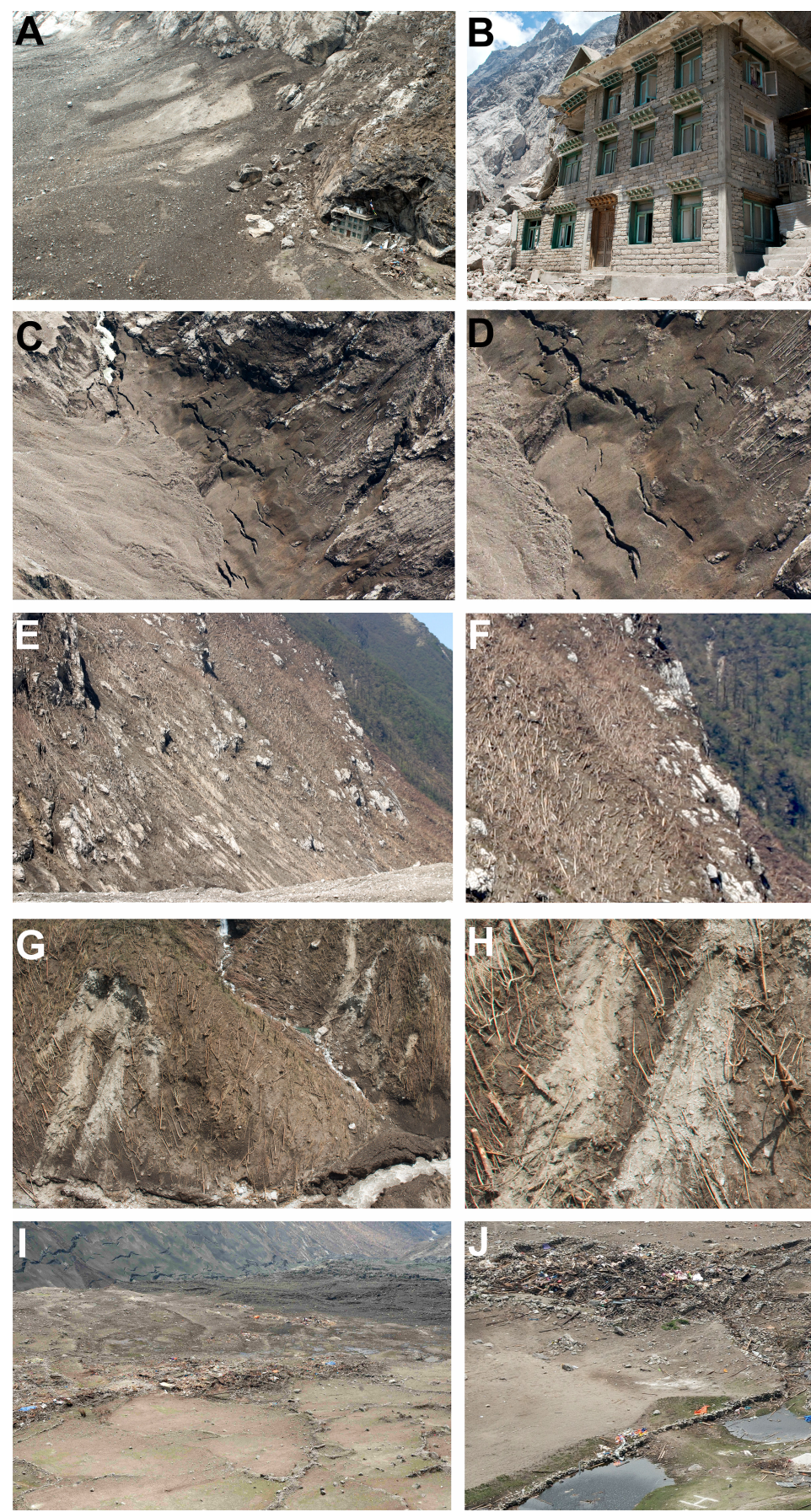

989

Fig. 7:

991

992

993

994

995

996

997

998

999 


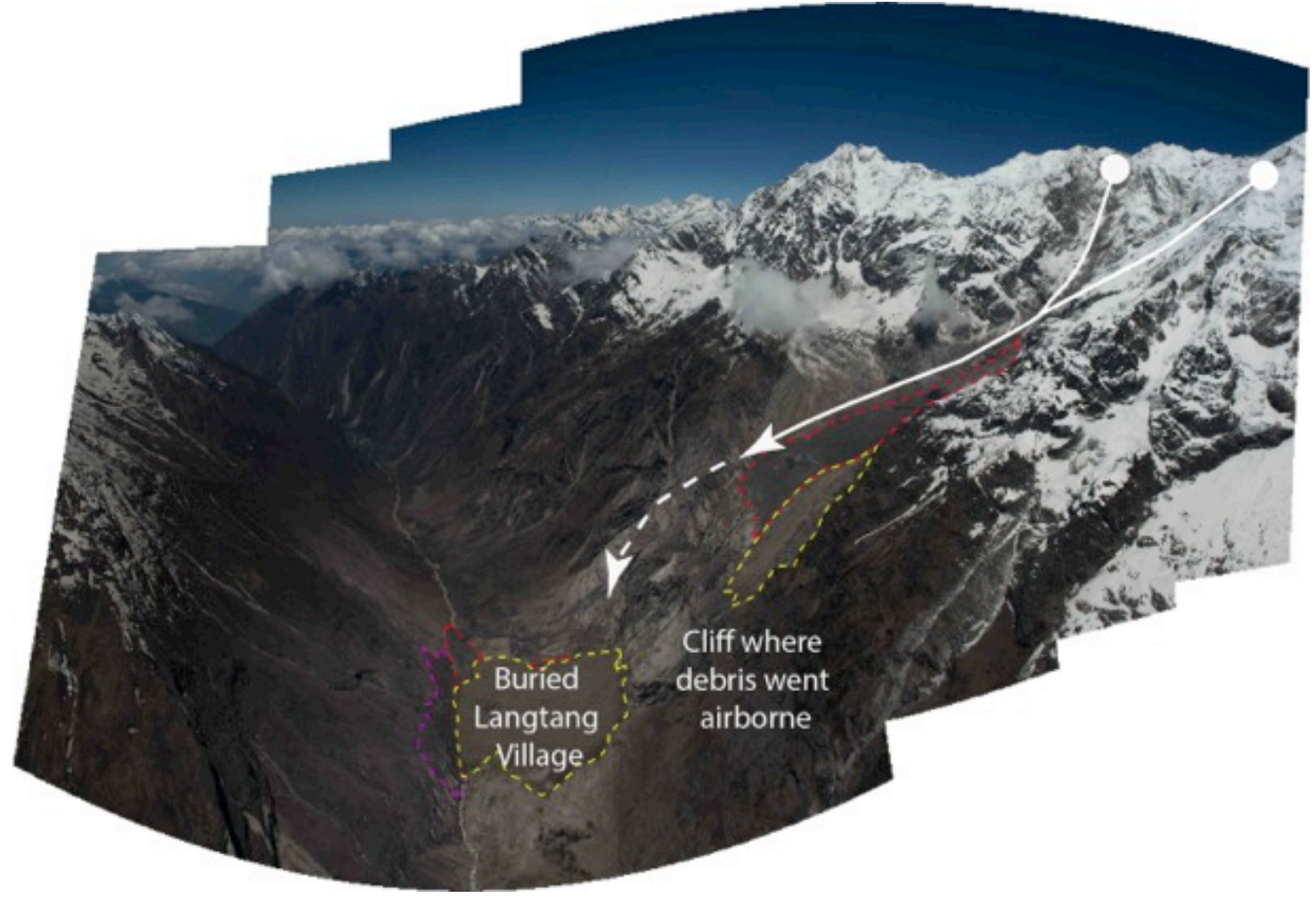

$1004 \quad$ Fig. 8.

1005

1006

1007

1008

1009

1010

1011

1012

1013

1014

1015

1016

1017

1018

1019

1020

1021

1022

1023

1024

1025

1026 


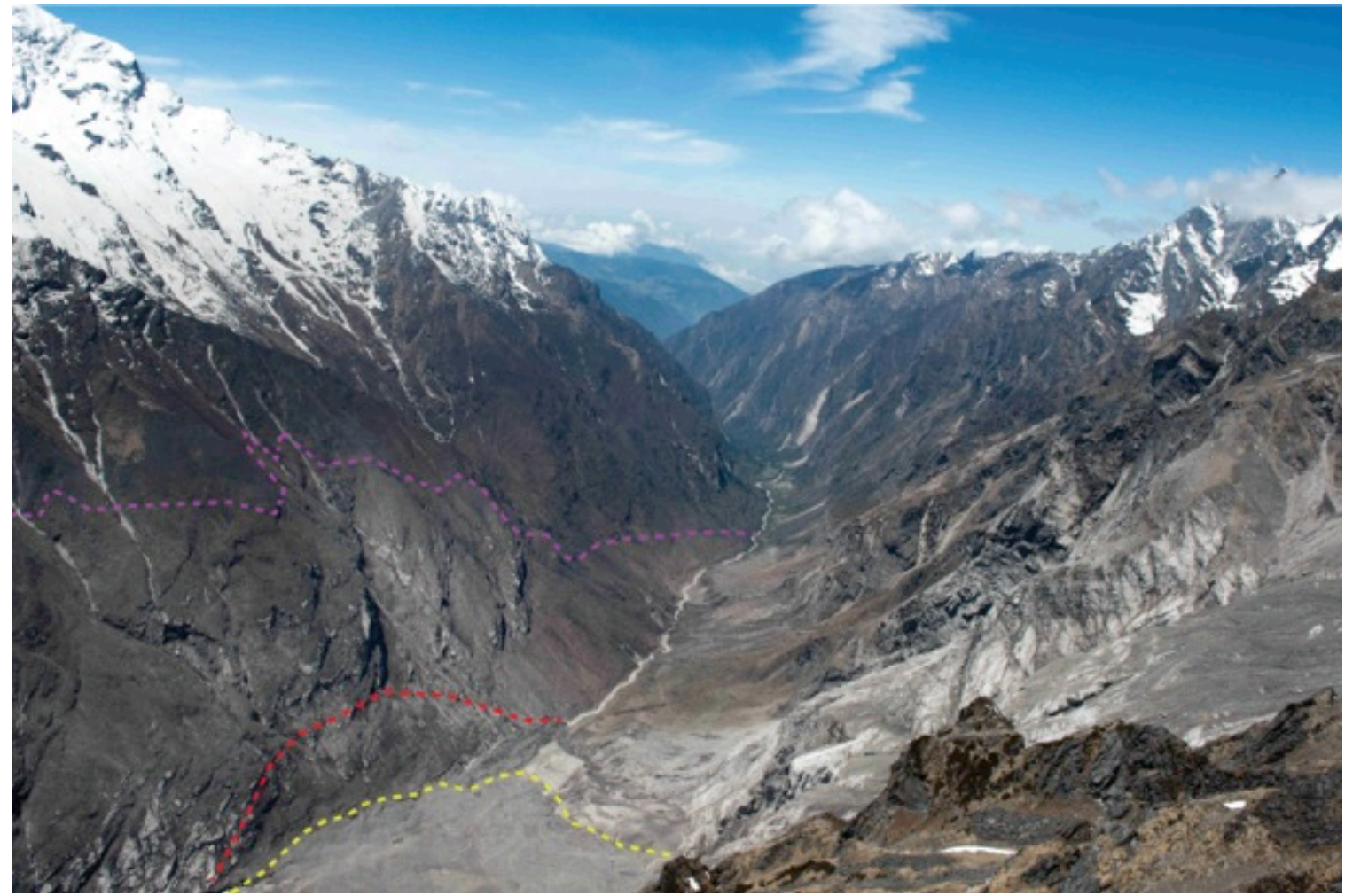
1031

1032

1033

Fig. 9.

1034

1035

1036

1037

1038

1039

1040

1041

1042

1043

1044

1045

1046

1047

1048

1049

1050

1051

1052

1053

1054

1055

1056

1057 

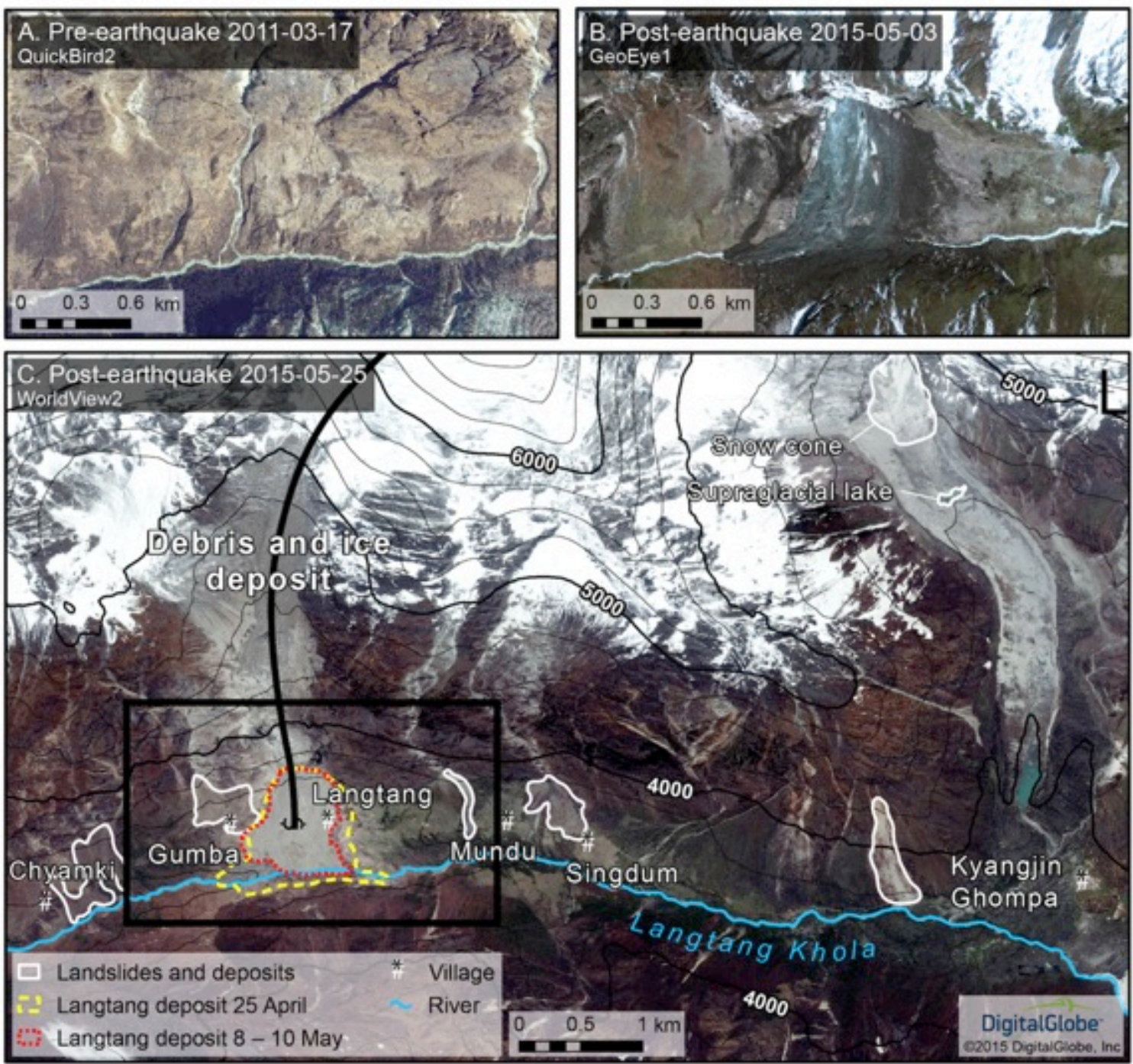

Fig. 10.

1062

1063

1064

1065

1066

1067

1068

1069

1070

1071

1072

1073

1074

1075 


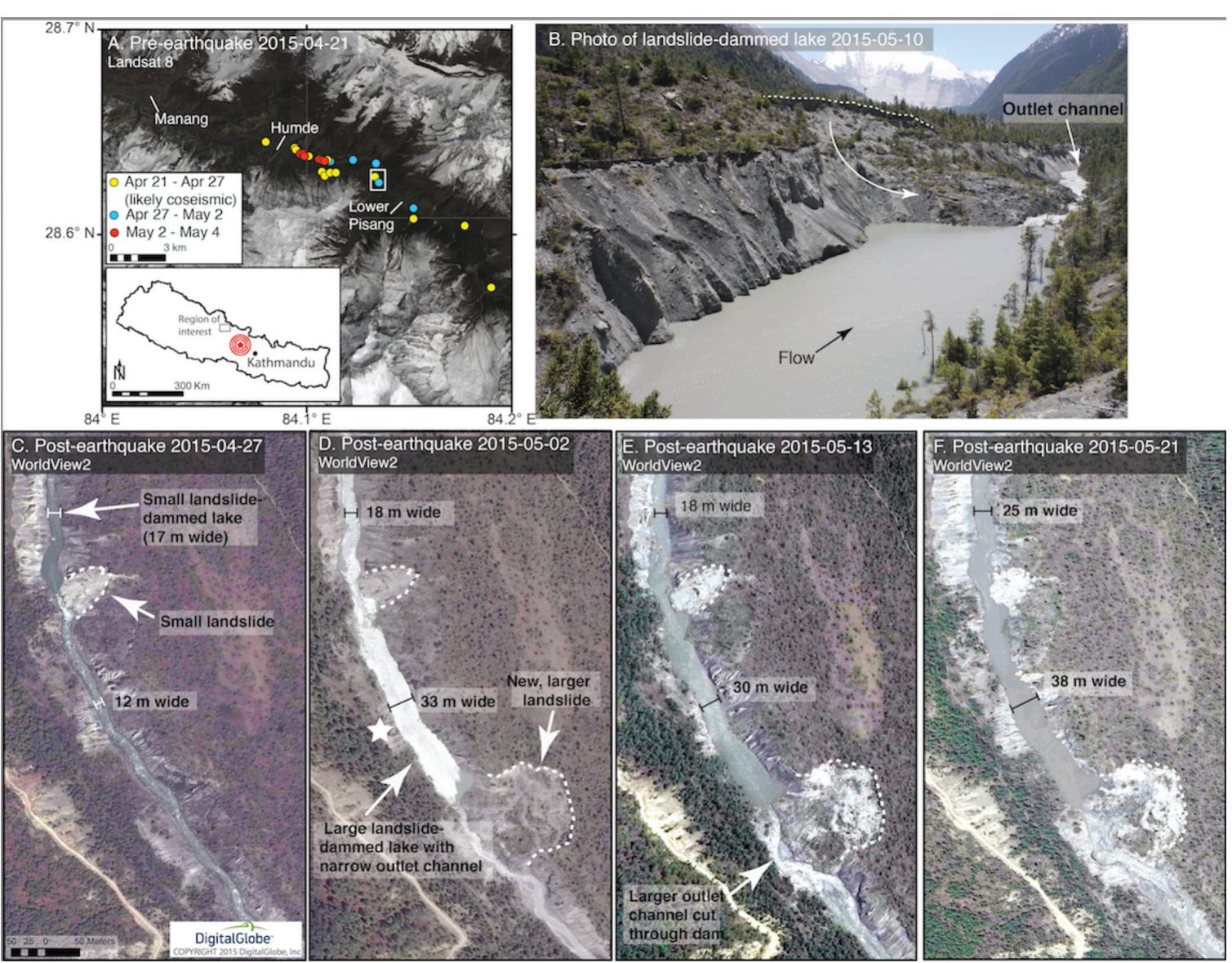



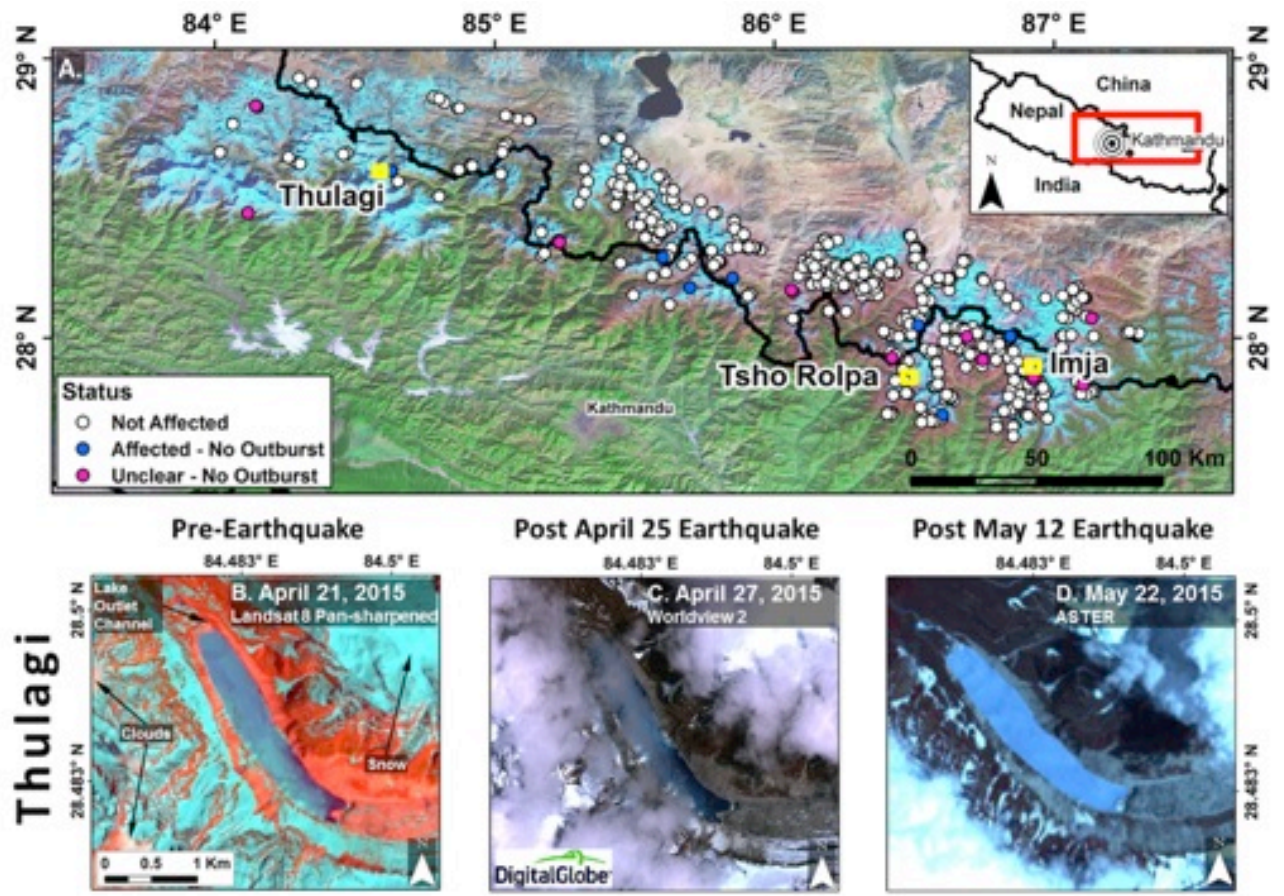

Post May 12 Earthquake
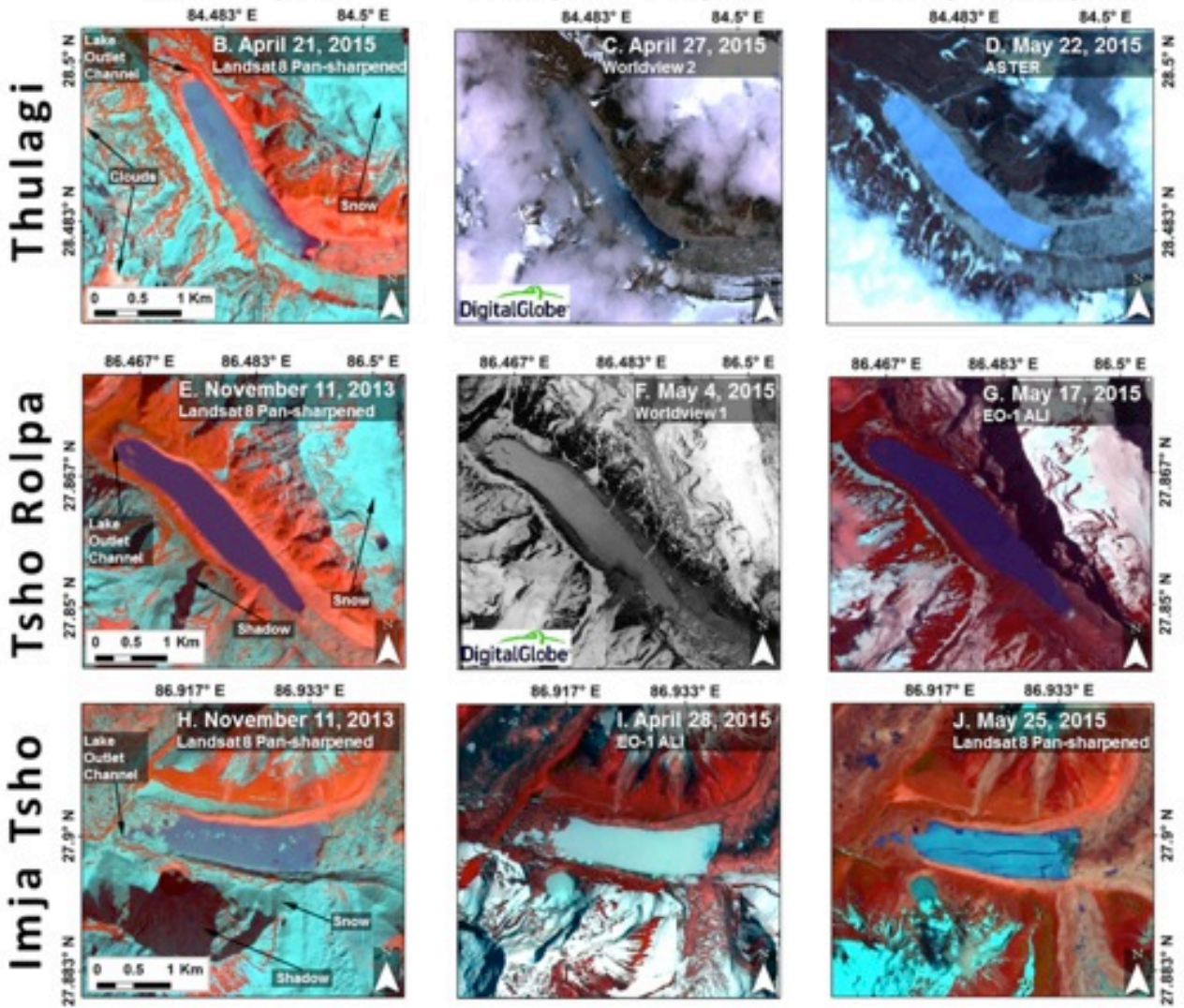

1102
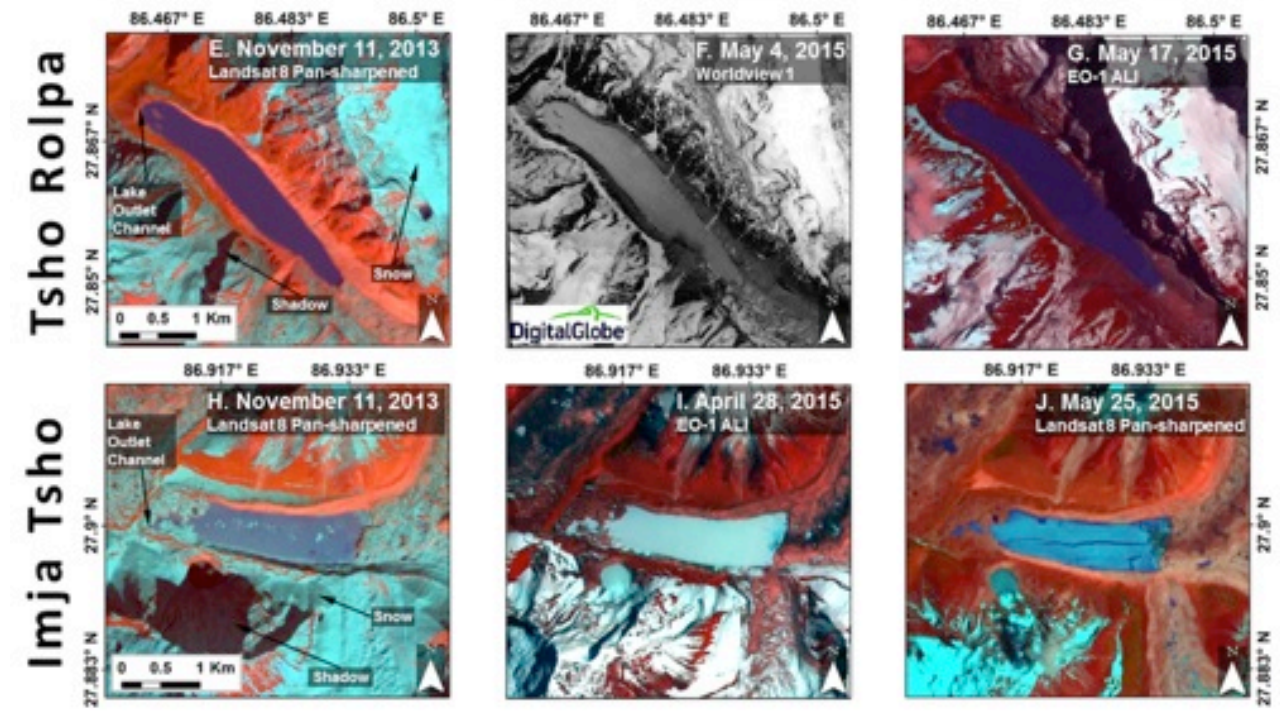

1104

Fig. 12.

1105

1106

1107

1108

1109

1110

1111

1112

1113 
1114

1115

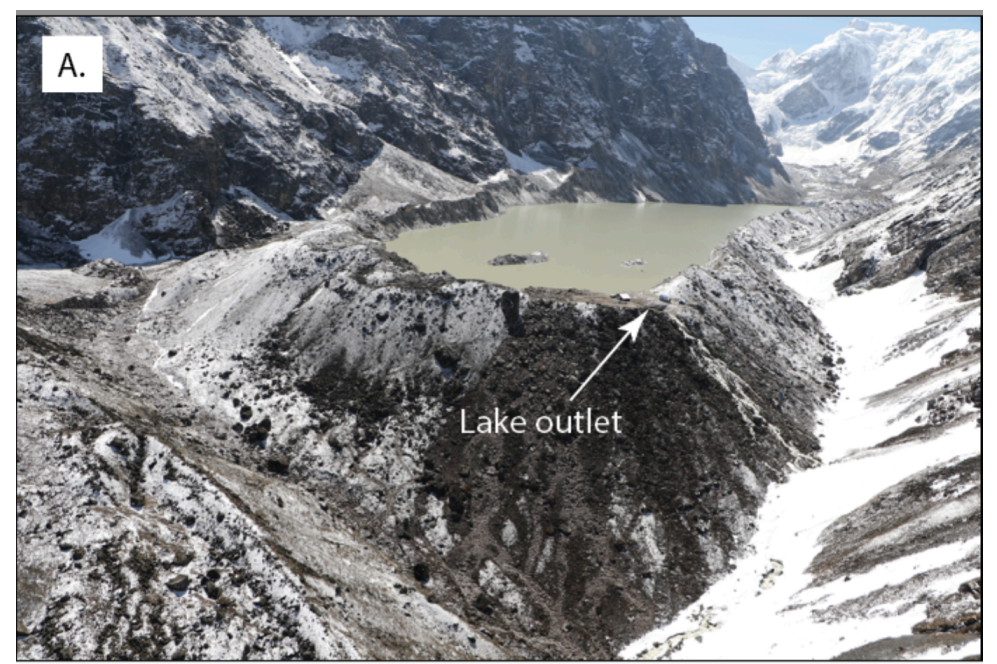

1116

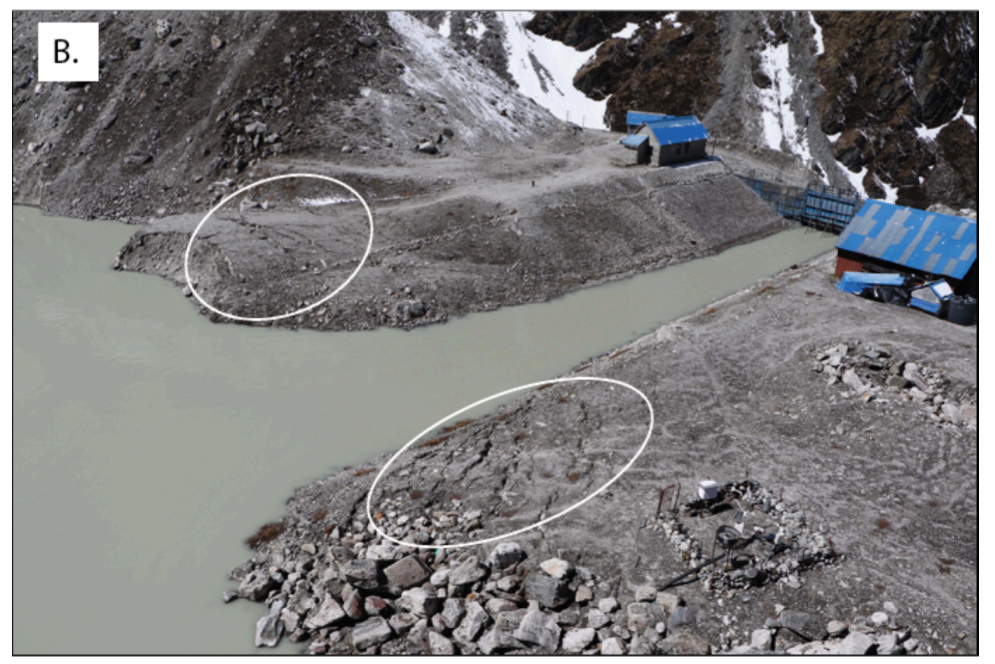

Fig. 13.

1118

1119 